Alma Mater Studiorum - Università di Bologna DEPARTMENT OF ECONOMICS

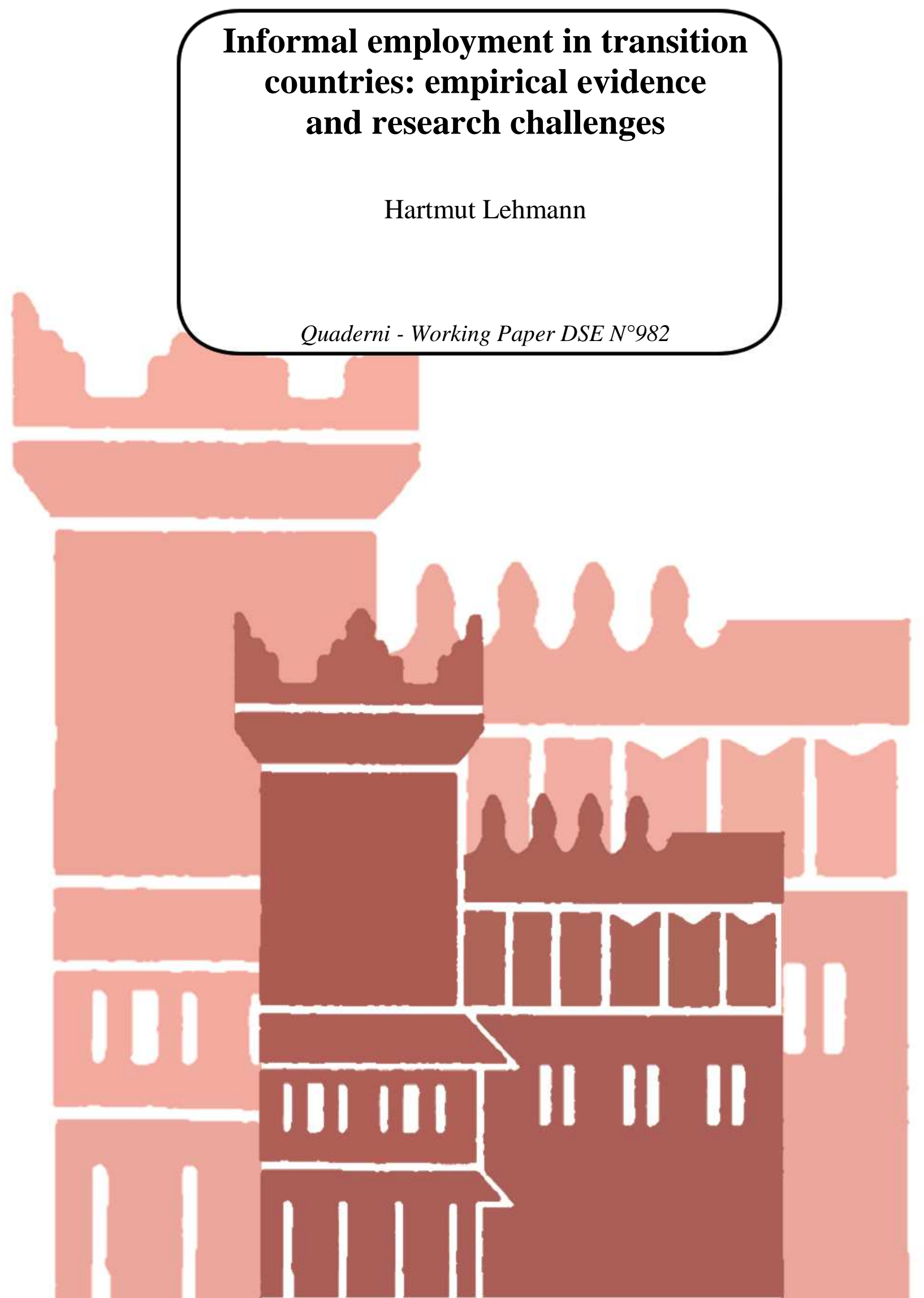




\title{
Informal employment in transition countries: empirical evidence and research challenges
}

Hartmut Lehmann, University of Bologna, Strada Maggiore 45, 40125 Bologna, Italy.

Institute for the Study of Labor (IZA), Bonn, Germany.

E-mail: hartmut.lehmann@unibo.it

\begin{abstract}
Even though informal employment is wide-spread in transition economies the literature on this phenomenon in the region is rather scarce. For policy makers it is important to know the incidence and the determinants of informal employment. In the first part of the paper we demonstrate that its incidence and to a lesser degree its determinants depend on the definition used. We then discuss studies that attempt to test for labor market segmentation in transition economies along the formalinformal divide. The presented results are inconclusive and we come to the conclusion that more work needs to be done before we can make definitive statements about whether labor markets are integrated or segmented in transition economies. Last but not least we introduce a new research area that links risk preferences and selection into labor market states. We show that if individuals have a choice, relatively risk loving workers have an increased likelihood to choose informal employment and self-employment.
\end{abstract}

Keywords: Informal employment, definitions, determinants, risk preferences, transition economies JEL Classification: D03, J43, P23 


\section{Introduction}

Many workers in all parts of the world are faced with informal employment relationships in their daily lives. The jobs of these workers in general do not provide any employment security or any protection in case of sickness and old age. Often informal jobs are also extremely hazardous to the health of workers. Informal employment thus poses major challenges to policy makers. These challenges can only be understood if we have a clear idea of what we mean by informal employment.

It is undisputed in the literature that development and informal employment are inversely related (see, e.g., La Porta and Shleifer 2008); so the bulk of informal jobs is found in developing and transition countries. The size of the informal sector is large in all areas of the transition region. The estimates of Schneider et al. (2010), however, show that its size increases as we go further east: the lowest numbers are found in Central and Eastern Europe and the Baltic States, with an average size of $24,3 \%$ of GDP in 2007, while the highest estimates are in the European CIS and the Caucasus, amounting to an average size of $47.6 \%$ of GDP in $2007 .{ }^{1}$ The paper focuses predominantly on Russia and Ukraine, because we have excellent data sets at our disposal that allow us to discuss some of the thus far unresolved issues in the literature in a refined way. The discussed issues are twofold.

First, how should we define (or measure) informal employment? From its definition depends its incidence in a labor market as we shall demonstrate in exemplary fashion with very detailed data taken from the Russian Longitudinal Monitoring Survey (RLMS). Furthermore, the empirical distributions of informal employment across, for example, industries and its determinants depend on the used definition. In other words, when providing a descriptive analysis of this phenomenon in the labor market and when estimating its size we need to be aware of how strongly the empirical

\footnotetext{
${ }^{1}$ These averages are not weighted by population size; there are just meant to demonstrate that informality is a large phenomenon in transition economies.
} 
estimates depend on the employed definitions. The first part of the paper will make this point by providing a more precise picture of informal employment in the Russian labor market over the last decade using a variety of definitions.

Second, even though researchers have analyzed informal employment in developing countries for decades, a generally accepted conceptual framework of how this type of employment and the labor market are intertwined does not exist. We can find at least three paradigms in the literature.

The traditional dualistic view, going back to Harris and Todaro (1970), sees the informal segment as the inferior sector, the option of last resort. Due to barriers to entry, minimum wages, unions or other sources of segmentation, formal jobs are rationed. Workers in the informal sector are crowded out from the formal sector involuntarily, their wage being less than that in the formal sector. ${ }^{2}$ For example, an increase in the statutory wage in the formal sector will reduce formal employment but lead to a lower informal wage and higher informal employment. During a recession informal employment and unregistered output expands because formal employment is reduced, while the informal labor market clears. In this view labor market segmentation between formality and informality is the defining feature of the labor market.

In contrast, in a competitive labor market one would expect workers to be able to move freely between occupations, and for wages (broadly interpreted) to equalize accordingly. In this view the informal and informal labor markets are not segmented, but integrated. Voluntary choice regarding jobs and particular attributes of these jobs, such as flexible hours, working as a self-employed and being one's own boss as a micro-entrepreneur, and not valuing social security benefits, can be the reasons for remaining in or moving to the informal sector (Maloney 1999, 2004; Cunningham and

\footnotetext{
${ }^{2}$ In this school of thought, formal sector jobs not only command higher wages but also provide fringe benefits that are absent with informal sector jobs (see also Mazumdar, 1976).
} 
Maloney 2001). Here, contrary to the segmentation case, formal and informal employment are not necessarily negatively correlated over the business cycle.

Segmentation and integration of the formal and informal labor markets are two very polar views regarding the interaction of formality and informality. However, as suggested by Tokman (1986) and Fields (1990), it is possible, given the heterogeneity of the informal labor market that these features co-exist in the same labor market. Tokman and Fields subdivide the informal labor market into two categories: an 'easy-entry' informal sector, which constitutes the involuntary segment, and an 'upper-tier' informal sector, where barriers of entry persist and in which participation is voluntary. Hence, the labor market is divided into the formal sector, a 'disadvantaged' subsistencelevel informal sector and the 'small firm' and micro-entrepreneur informal sector. ${ }^{3}$ How policy makers respond to growing informal employment in their economies will crucially depend on the paradigm they find most reasonable.

To test for labor market segmentation along the formal-informal divide researchers have employed two main tools: wage gap regressions and the estimation of transition probabilities between labor market states. We present the evidence on wage gaps citing the most credible studies on wage determination in transition countries that confront endogeneity and self-selection problems. A formal-informal wage gap at the mean of the wage distribution, with controls of observed and hopefully unobserved characteristics, is often taken as evidence of labor market segmentation. From our own work, we also report estimates of the wage gap across the entire wage distribution in the Russian labor market. These estimates can also provide a tentative answer to the question whether

\footnotetext{
${ }^{3}$ Laporta and Shleifer (2008) present three schools of thought that are related to our paradigms but have a pure firm perspective. The first paradigm is the dual view that finds the formal sector consisting of high-ability managers matched to high-quality assets and the informal sector consisting of low-ability managers matched to low-quality assets. This sorting leads to two parallel worlds that do not really interact, with a low-productivity informal sector and a highproductivity formal sector. The second paradigm is the parasitic view that maintains that informal firms are of low productivity but because they evade regulations and taxes can undercut prices of formally operating firms and thus take away costumers. In this parasitic view the informal sector hampers growth since it is of low productivity itself and reduces the activities of the high-productivity formal sector. The third view of the informal sector mentioned by Laporta and Shleifer is the romantic view, in the literature associated with the work of de Soto: the informal sector is actually or potentially vibrant with many very creative entrepreneurs who for the most part are held back by government regulations and taxes and insecure property rights. This romantic view gels with the idea of an integrated labor market.
} 
the informal sector is segmented into a lower involuntary and upper voluntary tier. Turning to transition probability estimates, we then discuss some evidence on the flows between labor market states that distinguishes between formal and informal employment. Larger flows from the informal to the formal sector, having taken account of the different size of these sectors, or low mobility between states both are thought to imply labor market segmentation.

A third and novel method to test for segmentation is to link risk attitudes and labor market states. The RLMS and the Ukrainian Longitudinal Monitoring Survey (ULMS) are two data sets that contain direct measures of risk attitudes and information on the voluntary/involuntary nature of informal employment. If persons who are willing to take more risks have a higher probability to engage in informal employment then we would discard the traditional paradigm of pure labor market segregation. If, on the other hand, there is no impact of risk attitudes on the likelihood of working informally, we can take this as evidence albeit tenuous that workers are rationed out of the formal labor market and do not choose informal jobs. Since we have information on the voluntary/involuntary nature of informal employment we refine this analysis by linking risk attitudes with involuntary and voluntary informal employment respectively.

Working in the informal sector constitutes a risk for the individual since there is no security of employment, income smoothing might be absent and there is the probability of detection and punishment by the authorities. We can moot that more risk loving persons will have a higher propensity to be engaged in informal employment. Having direct measures of risk preferences we can, therefore, also explore the fundamental question whether these preferences are an important predictor of employment status choice, and thus add to the evidence that establishes risk attitudes as an important predictor of microeconomic behavior, e.g., regarding occupational choice (Dohmen, Kriechel and Skriabikova 2012), migration behavior (Jaeger et al. 2010) and selection into selfemployment (Caliendo et al. 2014) 


\section{DEFINING INFORMAL EMPLOYMENT AND ITS INCIDENCE AND DETERMINANTS: EVIDENCE FROM THE RUSSIAN LABOR MARKET}

\section{Defining informal employment}

The definition of informality is a very complex issue as nicely exposited, for example, in chapter 1 of Perry et al. (2007) and in Kanbur (2009). There are essentially two broad groups of definitions in the literature: the "productivity-based" and the "legalistic" or social protection definitions. The first one characterizes informality in the labor market by job characteristics: non-professional selfemployed, unskilled workers, persons in marginal jobs, domestic and family workers and workers in small firms with up to 5 employees are all considered informal workers. The "legalistic" or social protection definition considers non-compliance with the regulations of the state regarding labor laws and social security systems as the defining characteristic of informality. Dependent workers who, in order to avoid paying taxes, do not pay social security and/or pension contributions or are prevented from doing so by their employers are considered informal. The self-employed who do not register their activities with the state are also considered informal.

We mainly use the "legalistic" definition in this paper since we find that using a "productivitybased” concept that defines informal or formal sectors would in transition countries be rather misleading. For example, to take all non-professional self-employed or workers in micro firms as belonging to the informal sector might be appropriate in a developing country but will introduce large measurement error in transition countries (see Lehmann and Pignatti, 2007, for discussion of Ukraine on this issue). In the case of the Russian labor market we demonstrate this assessment by contrasting "legalistic" measures with the firm-size measure.

Our "legalistic" measure uses the information from the reference weeks and defines an employment relationship as formal if dependent employees answer the following question by choosing option 1 , informal if they choose option 2: 
Tell me, please, are you officially registered at this job, that is on a work

roster, work agreement or contract?

1. Registered 2. Not Registered.

For the self-employed we use a similar question:

Is your activity registered?

1. Yes 2. $\mathrm{No}^{4}$

The self-employed decide for themselves whether to register their activity or not. We, therefore, think of all informal self-employed as voluntary informal self-employed. For employees we elicit the additional information about the (in-) voluntary nature of their informal job by asking the following question:

Why are you not officially registered at this job?

1. Employer does not want to register.

2. I do not want to register.

3. Both.

Answer 1 classifies a person as involuntary informal employed, answers 2 and/or 3 as voluntary informal employed. In the analysis of labor market segmentation and of the link between risk attitudes and informal employment we will work above all with these "legalistic" definitions. Before we turn to these issues we show in the following section, how in the Russian labor market the incidence but also the determinants of informal employment depend crucially on its definition.

$<$ Table $1>$

\footnotetext{
${ }^{4}$ The questions are identical in the RLMS and the ULMS.
} 


\section{Definitions, the incidence and the determinants of informal employment in the Russian labor}

market

Table 1 presents different measures of informal employment in Russia for the whole sample and with the data sliced by gender and education. The first measure is narrow and comprises only informal dependent employment at the main job, while the second measure is more general, including informal employees as main job holders, informal workers in a secondary job and all informal self-employed. The third measure takes firm size as the defining criterion. The fourth measure is the share of all workers who receive all or part of their wages as "envelope payments", that is, all or part of their wages are not taxed. Many of the workers with "envelope payments" can work in the formal sector and can have a formal contract. The fifth definition of informal employment includes employees without a contract and those who do not work in an enterprise/organization in the main or secondary job. The final definition is based on the nonavailability of the three most important mandatory benefits in Russia, paid vacations, paid sick leave and paid maternity leave.

As expected, using different measures of informality has different quantitative implications. Considering the whole sample, while the lowest incidence is given by dependent employees without a work/contract agreement in the main job (6 percent in 2011 relative to all employees), the highest numbers emerge if we use the definition based on envelope payments (around 19 percent in 2011) and the broadest employment-based definition that includes informal employees as well as those who do not work in an enterprise/organization (around 17 percent in 2011). It is also interesting to note that for all measures apart the one based on the lack of benefits informal employment has increased over the crisis.

Looking across gender and educational attainment, we see a clear ranking of the measures of informal employment. Workers with “envelope payments” and informal employees together with those not working in an enterprise/organization have clearly the highest incidence, followed by the 
broad measure based on informal employment and on benefits. The definition using firm size produces the next highest incidence of informal employment for the most part, although at times this measure gives a lower share of informal workers than the measure of informal main job holders (dependent employees) who in general have the lowest incidence.

In the years 2007 and 2011 female workers have a statistically significant lower incidence of informal employment. So, like in other transition economies (see Lehmann and Pignatti 2007) and in contrast to developing countries (see, e.g., Perry et al. 2007) female workers are less likely to have an informal job than men. However, when the criterion of firm size is used women seem to have a higher incidence of informal employment. This last result simply may point to the fact that the employment of female workers tends to be concentrated in smaller firms. Thus when one contrasts this result with the lower incidence of informal employment for women using the other three measures the potential weakness of the firm size measure becomes apparent. Educational attainment has a significant impact on the rate of informal employment as the last four panels of table 1 demonstrate. In 2011 apart from the measure based on firm size workers with secondary education have a lower incidence than workers with only primary education. In addition, in all years workers with higher education have a statistically significant lower incidence of informal employment than workers with secondary education no matter which measure of informal employment is used.

$<$ Figure 1>

Figure 1 shows the distribution of informal employment by industry using the most restrictive and the most encompassing "legalistic" definition in panels a and b respectively. Both panels demonstrate the large variation in the incidence of informal employment by sector, with construction and trade and related services showing by far the largest shares of informal employment. In addition, in light and food industry, transport, agriculture and in other sector we also find a relatively large incidence of informal employment. The distribution of informal employment across industries looks quite different if we take firm size as the defining criterion. The 
sector trade and related services still shows by far the highest incidence of informal employment whether we take 5 employees or less or 10 employees or less as our measure (panels a and b of Figure 2). What is striking, though, is that science and culture and public administration now exhibit relatively high shares of informal employment. What panel b of Figure 2 (firm size equal to 10 or less) in particular seems to indicate is that some workers in public administration and science and culture are employed in small work units. It is strikes us as rather unlikely that, e.g., 25 percent of workers in public administration are informally employed. Hence, while the measure using firm size equal or less than 5 employees might be acceptable when trying to capture a large chunk of informal employment, the measure based on firm size equal or less than 10 employees strikes us in the final analysis as inappropriate. It is also noteworthy to mention that the correlations between measures based on firm size equal or less than 5 employees and "legalistic" measures are small and insignificant (Lehmann and Zaiceva 2013); hence, the two types of measures cover different subsets of workers.

\section{$<$ Figure $2>$}

Which factors are the main determinants of informal employment? Are the identified determinants stable across a spectrum of different definitions of informal employment? Table 2, which summarizes the signed marginal effects across five definitions of informal employment for age, gender, marital status, educational attainment, regional location and residence type, tries to answer these questions. ${ }^{5}$ Informal employment decreases in age when we take the four "legalistic" measures, but increases in age when we use the firm-size measure. On this last measure male workers are less likely to be informally employed, while we find a higher probability of informal employment for male workers in the case of the first four measures. Being married and more educated decreases the likelihood of being informally employed no matter which measure of informal employment is used.

\footnotetext{
${ }^{5}$ The complete results of the probit regressions, on which table 2 is based, are presented in tables A2-A6 in the appendix of Lehmann and Zaiceva (2013).
} 
As far as location is concerned it is noteworthy that apart from the East dependent employees in Moscow and St. Petersburg have a higher probability to be informal than their counterparts in the rest of the country. When we extend the measure to informal self-employed and entrepreneurs the relative incidence is reversed for virtually all regions. It is also striking that residing in a village lowers the probability of being informally employed for the first four measures while this probability is increased if we use the criterion of firm size instead. Industry affiliation (not shown here) shows the same relative patterns that were found in Figures 1 and 2.

$<$ Table $2>$

The determination of informal employment, when using the "legalistic" measures on the one hand, and when using the firm-size measure on the other hand, shows divergent patterns in many cases. A second important upshot of the results presented in Table 2 is that the affirmation by Kapeliushnikov (2012) of a non-robust picture regarding the determinants of informal employment in Russia needs to be qualified. While the measure based on firm size does indeed produce a different set of determinants than the other measures, when we concentrate on the first four measures we find for the most part a broad congruence regarding the drivers of informal employment; thus one can speak of a roughly robust picture with respect to the determination of informal employment when considering these first four measures.

Since we have information about the voluntary nature of informal employment we use the legalistic measure of registration of one's job or activity to refine the analysis of the drivers of informal and formal employment. To this purpose we divide employment into five states: involuntary informal dependent employment, voluntary informal dependent employment, informal self-employment, formal self-employment and formal dependent employment. As already mentioned, we assume informal self-employment to be voluntary. 
Table 3 presents marginal effects of a multinomial logit regression spanning the years 2004 to 20011. While males have a higher incidence of both dependent informal employment and informal self-employment, the marginal effects of age, marital status and educational attainment have opposite signs when we distinguish between dependent and self-employment: these factors increase the likelihood to engage in informal self-employed activities, but decrease it for both voluntary and involuntary informal dependent employment. While being an immigrant from the Caucasus or Central Asia raises the likelihood of informal self-employment, immigrants from other parts of the former Soviet Union do not seem to be more involved in self-employment than natives, but seem to have a particularly high incidence of involuntary informal dependent employment. In summary, the presented marginal effects confirm our priors as far as the factors driving the selection into the five employment states are concerned.

$<$ Table $3>$

The presented evidence on the incidence and determinants of informal employment in Russia allows us to make some general remarks of how one should approach the analysis of informal employment in transition countries. Estimates of the incidence of informal employment depend crucially on the definition used; researchers need to use a gamut of definitions or measures to produce a reliable picture of the extent of informal employment in an economy. Second, using nonprofessional self-employment as a measure of informality, as often done in the literature (see, e.g., Laporta and Schleifer 2008), might be misleading in transition countries that start out with economies where the vast majority of workers are wage workers in formal jobs. Third, firm size strikes us to be a criterion of dubious value to pin down informal employment in transition countries since the correlations of workers in small firms and informal workers defined on the basis of one of the "legalistic" definitions are small and insignificant. In our opinion, measures that are based on "legalistic" criteria should be predominantly employed when analyzing the incidence and the determination of informal employment in transition countries. 


\section{THE EVIDENCE ON COMPETING PARADIGMS OF INFORMAL EMPLOYMENT: SEGMENTED VERSUS INTEGRATED LABOR MARKETS}

A main focus of the research on informality in transition countries has been the testing of labor market segmentation, employing two approaches. The first looks at the question whether there is a wage gap between similar workers who have formal and informal employment relationships. The second method looks at mobility between labor market states to assess whether there are barriers between the formal and informal segments of the labor market or whether workers can move freely between these two segments.

\section{Wage gap analysis}

We start off with the evidence on the wage gap along the formal-informal divide, which is very limited for transition countries. Evidence, which is based on cross-sectional data, is severely biased because of selection problems: unobserved characteristics such as ability or motivation might be important determinants of an individual's selection into a formal or informal job. Fixed effects estimates of wage differentials based on longitudinal data control for unobserved heterogeneity as long as the unobserved characteristics are time invariant and equally remunerated across jobs. Even though the use of longitudinal data has its own problems when assessing wage gaps (Solon 1988), we report on two studies that employ panel data (Pagés and Stampini 2009; Lehmann and Pignatti 2007) since they provide more reliable estimates of formal-informal wage gaps.

Pagés and Stampini analyze wage differentials in three transition countries: Albania, Georgia and Ukraine. They use cross-sectional and fixed effects regressions and difference-in-differences analysis to investigate whether there is a premium for formal jobs or for informal jobs in the three countries. They perform this analysis distinguishing between skilled and unskilled workers. The cross-sectional results establish a premium in informal jobs in Georgia for the unskilled and a formality premium in Ukraine across both skill levels. These results are overturned when 
longitudinal data are employed in the estimations. In Georgia the authors establish a wage gain for workers who change from formal to informal jobs, and this wage gain is larger for skilled workers than for their unskilled counterparts. In Ukraine, on the other hand, the formality premium disappears when unobserved characteristics are controlled for. So, in Ukraine the formal wage premium comes about because higher ability workers select themselves into formal jobs and not because jobs are of higher quality in the formal sector. In Georgia we have the astonishing results that higher ability workers seem to select themselves into informal jobs. Finally the results for Albania show no premium independent of the estimation method used. So, the evidence of Pagés and Stampini seems to point to integrated labor markets in the three analyzed transition countries.

The study by Lehmann and Pignatti (2007) uses the waves 2003 and 2004 of the Ukrainian Longitudinal Monitoring Survey (ULMS) ${ }^{6}$ to analyze labor market segmentation in Ukraine. Like Pagés and Stampini, who also use the ULMS, Lehmann and Pignatti estimate fixed effects and difference-in-differences regressions. They, however, use more detailed information on labor market states dividing employment into five mutually exclusive states: formal salaried, voluntary informal salaried, involuntary informal salaried, formal self-employment and informal selfemployment. The latter category includes informal entrepreneurs whose number in the sample is small, though. The ULMS has the same questions as the RLMS to determine whether informal salaried employment is voluntary or involuntary (see the section "Defining informal employment" above).

The fixed effects regressions take on three forms: simple fixed effects regressions, fixed effects regressions with a Heckman correction term for selection into employment categories and a Hausman-Taylor version of fixed effects. Relative to the default category, formal salaried, all versions show positive wage differentials for voluntary informal salaried, formal self-employment and informal self-employment, while there is no significant difference in the wages of formal

\footnotetext{
${ }^{6}$ For a detailed description of the ULMS see Lehmann, Muravyev and Zimmermann (2012).
} 
salaried and involuntary informal salaried workers. It is also noteworthy that the selection term is not significant in the Heckman selection correction version of the fixed effects regressions. This is maybe not that surprising given that the distinction between voluntary and involuntary informal employment points at self-selection of workers into a specific state. The difference-in-differences estimates of log hourly real earnings for movers versus stayers confirm the fixed effects regression results. There is no difference in the growth rates of hourly wages for formal salaried and involuntary informal salaried workers; however, for the other three employment categories hourly wages grow more than for formal salaried workers. This growth differential is particularly large for the informally self-employed.

The results on the Ukrainian labor market essentially say that once we control for self-selection into an employment state the wage differential between the formal and informal sector disappears. They also imply that the informal sector is in itself segmented since we find a positive wage premium for those who voluntarily choose informality, i.e., the voluntary informal salaried and the informal selfemployed.

$<$ Table $4>$

These outcomes are confirmed by very recent work on Russia done jointly with Anzelika Zaiceva. We illustrate some estimates from this work in Table 4 and Figure 3. The first 3 columns of Table 4 show OLS estimates that do not control for unobservable characteristics. Relative to formal employees the first two rows show the wage differentials for informal employees and for informal self-employed and entrepreneurs respectively. The OLS estimates establish a wage penalty for informal employees and an insignificant wage differential for informal self-employed and entrepreneurs once we control for sector and occupation (column 3). The outcome for informal employees is, however, not an expression of differences in job qualities as the fixed effects estimates in columns 4-6 attest. These latter estimates do not point to a significant wage differential; so once we control for time invariant unobserved characteristics such as innate ability and 
motivation informal employees are remunerated similarly to formal employees. On the other hand, like in the Ukrainian labor market informal self-employed and entrepreneurs receive a wage premium once we control for self-selection.

Additional information is contained in Figure 3 where we present the hourly wage gap over the entire wage distribution for informal employees (panel a) and the joint set of informal employees and informal self-employed and entrepreneurs (panel b). The figure is based on simple quantile regressions that do not control for unobserved individual heterogeneity. Estimates based on fixed effects quantile regressions where controls for this heterogeneity are included give qualitatively similar albeit somewhat attenuated results (see Bargain, Lehmann and Zaiceva 2014). We only present the estimates of the wage gap based on the simple quantile regressions here.

\section{$<$ Figure $3>$}

Low skilled informal employees experience a statistically significant and economically meaningful wage penalty while informal employees with high skills have the same wages as their formal counterparts. Hence Figure 3 tells us that for highly skilled informal employees, having a share of roughly $30 \%$ of informal salaried employment, the labor market is integrated; in contrast, the majority of salaried informal workers, who have lower skills, are confronted with a segmented labor market in Russia. When we add the self-employed and entrepreneurs to dependent employees the picture changes dramatically. Now the informal sector seems segmented in the sense of Tokman (1986) and Fields (1990) since we have a lower part of the distribution with wage penalties (a free entry lower tier) and an upper part with positive wage differentials (an upper rationed upper tier).

\section{Mobility analysis}

How mobile are workers in labor markets of transition countries across the formal-informal divide? Researchers use transition probability matrices in various forms to approach this question. They look at simple $\mathrm{P}[\mathrm{i}, \mathrm{j}]$ matrices where $\mathrm{i}$ and $\mathrm{j}$ are the origin and destination states respectively and $\mathrm{P}$ is 
the estimated probability of movement between these two states. Let i represent informal employment and $\mathrm{j}$ formal employment. When $\mathrm{P}[\mathrm{i}, \mathrm{j}]>>\mathrm{P}[\mathrm{j}, \mathrm{i}]$, this seems to imply that there is a much higher likelihood of flowing from informal into formal employment than vice versa. Hence workers supposedly queue in the informal sector to enter formal employment, which is taken as evidence of labor market segmentation. This simple comparison of flows has been criticized insofar as it does not take into account the different turnover rates across labor market states. If most of the workforce is employed formally and the informal sector is comprised of only a small share of the workforce it is just a statistical artifact that the transition rate from informal to formal employment is a multiple of the transition rate from formal to informal employment. To account for this artifact researchers produce transition matrices that are adjusted for the relative size of a state and for its capacity to generate vacancies. The studies by Lehmann and Pignatti (2007) on Ukraine, by Pagés and Stampini (2009) on 3 Latin American and 3 transition countries ${ }^{7}$ and by Slonimczyk and Gimpelson (2013) on Russia explicitly discuss how simple transition matrices need to be transformed to achieve comparability of the transition probabilities across states of different size. Slonimczyk and Gimpelson (2013) raise the additional issue that movements between labor market states are also determined by unobserved characteristics and that persons with different characteristics select themselves into different states. Once we take account of the unobserved characteristics as drivers of self-selection into informal or formal employment the large difference in transition rates might be attenuated or disappear.

Lehmann and Pignatti (2007) look at four and seven labor market states when they analyze transitions in Ukraine in the years 2003 and 2004. By splitting employment into its formal and informal parts and by also having unemployment and inactivity they arrive at four labor market states, while they get seven states by disaggregating the employment state into formal salaried employment, informal voluntary and informal involuntary salaried employment, formal self-

\footnotetext{
${ }^{7}$ The three transition countries are Albania, Georgia and Ukraine.
} 
employment and informal self-employment. The distinction between voluntary and involuntary informal employment takes care, at least partially, of the selection issues raised by Slonimczyk and Gimpelson (2013). ${ }^{8}$ The transition analysis is done for three age groups of workers: the young, the core group of workers (25 - 49 years of age) and older workers. We report the results of the core group of workers.

The simple P-matrix estimated for four states shows a large statistically significant difference of the transition rates from formal to informal employment (0.03) and from informal to formal employment (0.23). When adjusted for the smaller size of the informal sector these rates become 0.34 and 0.37 respectively and show no statistically significant difference. The authors get similar results when they only look at individuals who move between labor market states. Estimating transitions between seven labor market states does not change this picture in a substantial way. So, once the transition matrices are standardized by the size of the destination state we can infer that workers are able to freely move between states. Hence the Ukrainian labor market seems to be integrated.

Based on their evidence Pagés and Stampini (2009) come to somewhat different conclusions as far the Ukrainian labor market is concerned. They estimate P-matrices and counterfactual matrices (Zmatrices) that assume no labor market segmentation. The ratios of entries in the two matrices can according to the authors tell us whether the labor market is segmented and whether workers prefer formal over informal jobs. When these ratios are close to one the labor market is perfectly integrated and workers move freely between formal and informal employment without having a preference for one or the other labor market state.

However, in all three analyzed transition countries they find that the ratios for flows (P[i,j]/Z[i,j]) from informal to formal salaried employment are far greater than one, while for the reverse flows these ratios hover around one. For example, their evidence on unskilled Ukrainian workers shows a

\footnotetext{
${ }^{8}$ Lehmann and Pignatti treat informal self-employment as voluntary.
} 
ratio of 1.59 for transitions from informal to formal employment and a ratio of 0.88 for the reverse flows. The numbers for skilled Ukrainian workers are 1.78 and 1 respectively. The authors infer from their evidence on all three transition countries that there is some segmentation in the labor markets of these countries and that workers strongly prefer formal salaried employment over working as dependent employees in the informal sector. Movements between self-employment and salaried formal employment show much lower ratios pointing to more segmentation between these two sectors in the three analyzed transition countries.

The last paper we briefly discuss is by Slonimczyk and Gimpelson (2013) who look at the Russian labor market. Using transition analysis they focus on state dependence, i.e. the propensity to remain in the given sector. If state dependence is large this is an indication of labor market segmentation; if, on the other hand, it is small then workers can freely move between labor market states and a competitive, integrated labor market can be inferred. The transition matrices initially presented by the authors imply large state dependence, in particular for workers in the informal state. However, once the authors control for unobserved heterogeneity state dependence is strongly reduced and workers seem to be able to easily move from informal to formal employment. Hence they conclude that "the labor market in Russia is competitive and relatively flexible. In fact, none of the labor market institutions that are generally seen as possible causes of informality are strict enough to cause segmentation in the Russian setting.” Slonimczyk and Gimpelson embed their evidence into the context of Russian labor market institutions, i.e., very low minimum wages and public sector pay, weak trade unions and poorly enforced regulations. That their evidence on Russia is congruent with the evidence provided by Lehmann and Pignatti on Ukraine is thus not very surprising given that Ukrainian labor market institutions are very similar to those in Russia.

The brief discussion of the literature on worker mobility across the formal-informal divide leaves us with the impression that a lot more research needs to be done before we can make definitive statements about labor market segmentation in transition countries or the lack thereof. Ideally, one 
would need relatively long panel data that permit the identification of those measures of informality that are most relevant in transition countries. Such data should be collected for as many transition countries as possible and should be used to rigorously test formal-informal wage gaps and worker mobility between labor market states. Unfortunately we are far away from such a concerted effort.

\section{RISK ATTITUDES AND INFORMAL EMPLOYMENT}

The impact of risk attitudes on economic behavior at the micro level is a very interesting and important new research area. In the context of the labor market the papers by Jaeger et al. (2010), Dohmen, Kriechel and Skriabikova (2013) and Caliendo et al (2014) are particularly noteworthy. In the first study the authors look at the relationship between risk attitudes and the decision to migrate, showing that individuals with a higher propensity to take risks are more prone to migrate. In the setting of a quasi-natural experiment in the Ukrainian labor market, Dohmen et al. study occupational sorting and establish that workers with a larger propensity to take risk sort into occupations with higher earnings risk. In the third study the authors find that risk-takers are more likely to become and stay self-employed.

The studies by Dohmen, Khamis and Lehmann (2014) on the Ukrainian labor market and Lehmann and Zaiceva (2013) on the Russian labor market link risk preferences and selection into various labor market states, among them informal employment. Direct measures of risk preferences and detailed information on informality in the two countries collected in the 2007 wave of the ULMS and in the 2009 supplement of the RLMS make this analysis in transition economies for the first time possible. The principal hypotheses underlying the two studies are that informal employment is 
an inherently risky state ${ }^{9}$ and that workers who have a higher tendency to take risks are more likely to consider informal employment.

The modules on risk attitudes in the ULMs and the RLMS are similar to the modules of the German Socioeconomic Panel (GSOEP). There are essentially three types of risk attitudes measures that one can recover from these modules: (a) self-assessed "subjective" measures of risk preferences of the general type and specific to life domains, (b) “objective” measures linked to hypothetical investment questions and (c) lottery questions. Dohmen et al. (2014) and Lehmann and Zaiceva (2013) concentrate on the self-assessed "subjective” measures. The question on self-assessed risk preferences is as follows:

How do you see yourself? Are you generally a person who is fully willing to take risks or do you try to avoid taking risks? Please give a number from 0 to 10, where the value 0 means: "Completely unwilling to take risks" and the value 10 means "Completely willing to take risks”. You can take the values in between to make your estimate.

For risk attitudes specific to a life domain like, e.g., career or financial matters, the question asks:

People can behave differently in different situations. How would you rate your willingness to take risks in career/financial matters?

Respondents are given the same scale as with the question regarding general risk attitudes. These measures have been experimentally validated with the GSOEP data: when properly incentivized there exists a clear congruence between the actions of respondents in an experimental setting and the level of self-assessed risk preferences in the German case. The working hypothesis of the studies by Dohmen et al. (2014) and Lehmann and Zaiceva (2013) is that this validation can be generalized to the Russian and Ukrainian data.

\footnotetext{
${ }^{9}$ It is inherently risky since, e.g., there is the risk of detection and subsequent punishment, the risk of immediate layoff and the risk of ending up ill or beyond working age without social security coverage.
} 
Figures 4 and 5 show the distributions for the general risk index in Ukraine and Russia. In both countries one fifth of workers are completely risk averse. It is also noteworthy that in Ukraine people tend to be somewhat more risk averse than in Russia. In the regressions that we report below we also use a risk indicator, which is a binary variable taking the value 0 (relative risk aversion) when the risk index is a number between 0 and 5, and taking the value 1 (relative risk loving) when the risk index is a number between 6 and 10. Inspection of Figures 4 and 5 leads us to conclude that roughly three quarters of Ukrainian and Russian workers are relatively risk averse.

\section{$<$ Figure $4>$ \\ $<$ Figure $5>$}

Figures 6 and 7 link risk attitudes to labor market states. In both countries formal employees are the most risk averse while the self-employed show the highest propensity to take risk. This is confirmed by the averages of the risk index across labor market states and demographic characteristics shown in Table 5 for Ukraine. Going across columns we can clearly see that no matter what the demographic characteristic the average of the risk index is the lowest for formal employees, while the averages for informal employees and self-employed are grosso modo close to each other. Finally workers who are voluntarily in informal dependent employment are more risk loving by roughly half a unit, while there is little difference in the average risk indices of the formally selfemployed and the informally, i.e., not registered, self-employed. ${ }^{10}$

\footnotetext{
$<$ Figure $6>$

$<$ Figure $7>$

$<$ Table $5>$
}

\footnotetext{
${ }^{10}$ To save space we do not discuss the risk index averages across demographics or regions. As far as the demographics are concerned the relative magnitudes definitely confirm our priors.
} 
Table 6 summarizes the results of regressing the probability of being in informal employment on various risk measures while controlling for demographics, income, migration status, sector, occupation and region. Before interpreting the results it is important to discuss whether these regressions, which use cross-sectional data, show correlations or causal effects. The studies on Germany by Dohmen et al. (2011) and on Ukraine by Dohmen et al. (2014) show that risk attitudes have a very long gestation period. Moreover, the latter paper finds that being in informal employment continuously over a long period has no significant effect on risk attitudes. In other words, a labour market experience of informality spanning several years does not alter workers’ risk attitudes. We are thus quite confident that the shown effects can be interpreted as causal.

The upper panel of Table 6 shows the impact of general risk preferences and of risk preferences in the financial domain for Russia. Whether we use the risk index or the risk indicator we get statistically significant positive marginal effects. When the index increases by one unit, the probability of being in informal employment rises by one fifth of a percentage point in the general and in the financial domain. When we take the dichotomous risk indicator the results tell us that a relatively risk loving person has a propensity to select herself into informal employment that is between 1.3 and 2.2. percentage points higher than for a relatively risk averse person. We can put this into context by recalling that the incidence of informal employment is around 9\% between 2003 and 2011 if we sum informal salaried workers and the informal self-employed (see the first panel of Table 1). In addition, the coefficients on gender, education and regional location are of the same order of magnitude as the coefficients on the risk indicator variables (see Lehmann and Zaiceva, 2013). The effects for Ukraine, shown in the lower panel of Table 6 with respect to general risk preferences and risk preferences in the career domain, are very similar to those for the Russian labor market and have similar relative magnitudes. Hence risk preferences are important in predicting selection into informal employment in both countries. 
Dividing employment into five distinct states (involuntary informal dependent employment, voluntary informal dependent employment, formal dependent employment, informal and formal self-employment) is an additional tool to find out whether risk attitudes are indeed an important determinant of self-selection into a labor market state. When causality runs from risk attitudes to labor market state, dependent involuntary informal employment should not be determined by risk attitudes since workers do not enter this state by choice. On the other hand, we can assume that workers with a higher propensity to take risks are more likely to choose voluntary informal dependent employment or informal self-employment. We also hypothesize that self-employment in general, whether informal or formal, is associated with a higher propensity to take risks. Estimates of relative odds ratios of a multinomial logit model are presented in Table 7 for Russia in 2009. The odds ratios, given relative to formal employees, confirm our priors. The general risk index has no predictive power regarding involuntary informal dependent employment but does have a positive impact on the likelihood of being a voluntary informal employee or being self-employed. The positive relation between risk proclivity and self-employment is consistent with the study by Caliendo et al. (2014). When workers have a choice, their risk attitudes in addition to gender, age, marital status, educational attainment and household income constitute an important factor that determines the chosen employment state.

$<$ Table $7>$

\section{Conclusions}

Even though informal employment is wide-spread in transition economies the topic is understudied and our knowledge about this phenomenon in the region is very limited. This paper takes stock of the most pertinent literature discussing some crucial issues. For policy makers it is important to know the incidence and the determinants of informal employment. In the first part of the paper we demonstrate that its incidence and to a lesser degree its determinants depend on the definition used. We then discuss studies that attempt to test for labor market segmentation in transition economies 
along the formal-informal divide. The presented results are inconclusive and we come to the conclusion that more work needs to be done before we can make definitive statements about whether labor markets are integrated or segmented in transition economies. Last but not least we introduce a new research area that links risk preferences and selection into labor market states. We show that if individuals have a choice relatively risk loving workers have an increased likelihood to choose informal employment and self-employment. 


\section{Acknowledgments}

This paper is based on my presidential address to the 2014 Annual Meeting of the Association of Comparative Economic Studies, which I presented on 4 January 2014 in Philadelphia, Pennsylvania. I am grateful to Olivier Bargain, Thomas Dohmen, Melanie Khamis, Norberto Pignatti, Tiziano Razzolini, and Anzelika Zaiceva for allowing me to draw on joint work. Comments by Josef Brada, John Bennett and by participants of the ASSA meetings in Philadelphia and of the Second International Conference of the Institute for East and Southeast European Studies in June 2014 in Regensburg, where I gave an invited lecture on the same topic, are gratefully acknowledged. I am also grateful to the Fritz Thyssen-Foundation for partial financial support within the project "Risk attitudes and labor market informality: with a case study of Russia.” The opinions expressed in this paper are mine and should not be attributed to the University of Bologna or IZA.

\section{REFERENCES}

Bargain, O., Lehmann, H. and Zaiceva, A. 2014. The Great Recession and Informal Employment in Russia: The Evolution of the Informal-Formal Wage Gap. IZA Discussion Paper forthcoming, December.

Caliendo, M., Fossen, F. M. and Kritikos, A. S. 2014. Personality Characteristics and the Decision to Become and Stay Self-Employed. Small Business Economics 42 (4): 787-814.

Cunningham, W. V. and Maloney, W. F. 2001. Heterogeneity among Mexico’s Microenterprises: An Application of Cluster and Factor Analysis. Economic Development and Cultural Change 50 (1): $131-156$. 
Dohmen, T., Kriechel, B. and Skriabikova, O. 2012. Risk Attitudes and Occupational Choice, ROA, Maastricht University, mimeo.

Dohmen, T., Khamis, M. and Lehmann, H. 2013. Risk attitudes and the Incidence among Workers: Evidence from a Transition Country. Bonn, Middletown, CT and Bologna, mimeo.

Dohmen, T., Falk, A., Huffman D.B., Sunde, U., Schupp, J. and Wagner, G.G. 2011. Individual Risk Attittudes: Measurement, Determinants and Behavioral Consequences. Journal of the European Economic Association 9 (3): 522-550.

Fields, G. S. 1990. Labour market modelling and the urban informal sector: theory and evidence. In: D. Thurnham, B. Salomé and A. Schwarz (eds.) The Informal Sector Revisited, OECD. Paris.

Harris, J. R. and Todaro, M.P. 1970. Migration, Unemployment and Development: A Two Sector Analysis. American Economic Review 60: 126-142.

Jaeger, D.A., Bonin, H., Dohmen, T., Falk, A., Huffman D.B. and Sunde, U. 2010. Direct Evidence on Risk Attitudes and Migration. Review of Economics and Statistics 92(3): 684-689.

Kanbur, R. 2009. Conceptualising Informality: Regulation and Enforcement. Ithaca, New York, February, mimeo.

Kapeliushnikov, R. I. 2012. Informal Employment in Russia: What do the Alternative Definitions Say? (in Russian: Neformalnaja Zaniatost v Rossii: Chto Govoriat Alternativnyje Opredelenija). Higher School of Economics Working Paper WP3/2012/04.

La Porta, R. and Shleifer, A. 2008. The Unofficial Economy and Economic Development. Brookings Papers on Economic Activity, Fall: 275 - 352.

Lehmann, H. and Zaiceva, A. 2013. Informal Employment in Russia: Incidence, Determinants and Labor Market Segmentation. University of Bologna, Department of Economics, Working Paper DSE N903. 
Lehmann, H., Muravyev, A. and Zimmermann, K.F. 2012. The Ukrainian Longitudinal Monitoring Survey: Towards a better Understanding of Labor Markets in Transition. IZA Journal of Labor and Development 1:9.

Lehmann, H. and Pignatti, N. 2007. Informal Employment and Labor Market Segmentation in Transition Economies: Evidence from Ukraine. IZA Discussion Paper No. 3269. Institute for the Study of Labor, IZA, Bonn.

Maloney, W.F. 1999. Does Informality Imply Segmentation in Urban Labor Markets? Evidence from Sectoral Transitions in Mexico. The World Bank Economic Review 13 (2): 275 - 302.

Maloney, W. F. 2004. Informality Revisited. World Development 32: 1159-1178.

Mazumdar, D. 1976. The Urban Informal Sector. World Development 4 (8): 655-679.

Pagés, C. and Stampini, M. 2009. No Education, no Good Jobs? Evidence on the Realtionship between Education and Labor Market Segmentation. Journal of Comparative Economics 37 (2): $387-401$.

Perry, G., Maloney, W. Arias, O. Fajnzylber, P. Mason, A. and Saavedra-Chanduvi, J. 2007. Informality: Exit and Exclusion. Washington DC: World Bank.

Schneider, F. Buehn, A. and Montenegro, C.E., 2010.: New estimates for the Shadow Economies all over the World. International Economic Journal, 24 (4), pp. 443-461.

Slonimczyk, F. and Gimpelson, V. 2013. Informality and Mobility: Evidence from Russian Panel Data, IZA Discussion Paper No. 7703. Institute for the Study of Labor, Bonn.

Solon, G. 1988. Self-Selection Bias in Longitudinal Estimation of Wage Gaps. Economic Letters 28 (3): $285-290$.

Tokman, V. 1986. The Informal Sector: Fifteen Later. Paper presented at the Conference "The Comparative Study of the Informal Sector.” Harper’s Ferry, October. 
Table 1: Incidence of informal employment: overall and by gender, education and migration status by various definitions - Russian Labor Market

\begin{tabular}{|c|c|c|c|}
\hline & 2003 & 2007 & 2011 \\
\hline & & Overall & \\
\hline Empl. inform., main job & 0.053 & 0.059 & 0.060 \\
\hline Empl. inform. , All & 0.089 & 0.097 & 0.094 \\
\hline Firm size $<=5$ & 0.070 & 0.070 & 0.083 \\
\hline Wage informal & n.a. & 0.180 & 0.186 \\
\hline Inform., not enterprise, main and sec. jobs & 0.141 & 0.164 & 0.168 \\
\hline \multirow[t]{2}{*}{ No three main benefits, main and sec. jobs } & 0.111 & 0.100 & 0.103 \\
\hline & & Male & \\
\hline Empl. inform., main job & 0.061 & 0.075 & 0.078 \\
\hline Empl. inform. , All & 0.095 & 0.113 & 0.112 \\
\hline Firm size $<=5$ & 0.056 & 0.048 & 0.075 \\
\hline Wage informal & n.a. & 0.207 & 0.202 \\
\hline Inform., not enterprise, main and sec. jobs & 0.155 & 0.188 & 0.199 \\
\hline \multirow[t]{2}{*}{ No three main benefits, main and sec. jobs } & 0.120 & 0.114 & 0.129 \\
\hline & & Female & \\
\hline Empl. inform., main job & $0.047 * *$ & $0.045^{* * *}$ & $0.046 * * *$ \\
\hline Empl. inform. , All & 0.083 & $0.082^{* * *}$ & $0.077 * * *$ \\
\hline Firm size $<=5$ & 0.081 & $0.086^{* * *}$ & $0.090 * *$ \\
\hline Wage informal & n.a. & $0.159 * * *$ & $0.173 * * *$ \\
\hline Inform., not enterprise, main and sec. jobs & $0.130 * * *$ & $0.144^{* * *}$ & $0.142^{* * *}$ \\
\hline \multirow[t]{2}{*}{ No three main benefits, main and sec. jobs } & $0.102 * *$ & $0.087 * * *$ & $0.082 * * *$ \\
\hline & & Primary education & \\
\hline Empl. inform., main job & 0.079 & 0.098 & 0.112 \\
\hline Empl. inform. , All & 0.099 & 0.116 & 0.126 \\
\hline Firm size $<=5$ & 0.090 & 0.075 & 0.106 \\
\hline Wage informal & n.a. & 0.223 & 0.244 \\
\hline Inform., not enterprise, main and sec. jobs & 0.167 & 0.209 & 0.253 \\
\hline \multirow[t]{2}{*}{ No three main benefits, main and sec. jobs } & 0.122 & 0.103 & 0.137 \\
\hline & & Secondary education & \\
\hline Empl. inform., main job & $0.056 * *$ & $0.063^{* * *}$ & $0.070 * * *$ \\
\hline Empl. inform. , All & 0.096 & 0.104 & $0.103^{* *}$ \\
\hline Firm size $<=5$ & 0.079 & 0.078 & 0.095 \\
\hline Wage informal & n.a. & 0.207 & $0.204^{* *}$ \\
\hline Inform., not enterprise, main and sec. jobs & 0.151 & $0.181^{* *}$ & $0.186 * * *$ \\
\hline \multirow[t]{2}{*}{ No three main benefits, main and sec. jobs } & 0.111 & 0.112 & $0.113^{* *}$ \\
\hline & & Secondary education & \\
\hline Empl. inform., main job & 0.056 & 0.063 & 0.070 \\
\hline Empl. inform. , All & 0.096 & 0.104 & 0.103 \\
\hline Firm size $<=5$ & 0.079 & 0.078 & 0.095 \\
\hline Wage informal & n.a. & 0.207 & 0.204 \\
\hline Inform., not enterprise, main and sec. jobs & 0.151 & 0.181 & 0.186 \\
\hline \multirow[t]{2}{*}{ No three main benefits, main and sec. jobs } & 0.111 & 0.112 & 0.113 \\
\hline & & Higher education & \\
\hline Empl. inform., main job & $0.024 * * *$ & $0.027 * * *$ & $0.026 * * *$ \\
\hline Empl. inform. , All & $0.058 * * *$ & $0.066^{* * *}$ & $0.065 * * *$ \\
\hline Firm size $<=5$ & $0.036 * * *$ & $0.050 * * *$ & $0.057 * * *$ \\
\hline Wage informal & n.a. & $0.110 * * *$ & $0.140 * * *$ \\
\hline Inform., not enterprise, main and sec. jobs & $0.092 * * *$ & $0.096 * * *$ & $0.106 * * *$ \\
\hline No three main benefits, main and sec. jobs & 0.098 & $0.070 * * *$ & $0.073 * * *$ \\
\hline
\end{tabular}

Notes: ***,**,* denotes that difference in means for a corresponding category is significant at the 1, 5 and 10 percent level. "Wage informal” is from 2009 instead of 2007; for benefits, 2010 is used instead of 2011. Immigrants refer to those born in the former USSR republics apart from Russia or in other countries.

Table labels: "Empl. inform.. main job” stands for informal employees, main job. "Empl. inform. , All” stands for informal employees, main job , second job and informal self-employed (see text for exact definitions of self-employed). "Inform., not enterprise, main and sec. jobs" includes informal employees and those working not in 
enterprise/organization, main and second jobs. "Inform., not enterprise, main and sec. jobs and additional irregular informal activities” includes in addition those who report undertaking informal irregular/occasional additional activities. "Firm size $<=5$ " stands for firm size of 5 employees or less. "Wage informal" refers to the share of workers who think that part or all of their wages at the main job were not official, that is, their employer did not pay taxes it. "No three main benefits, main and sec. jobs” refers to the share of workers for whom three compulsory benefits (paid vacations, paid sick leave, maternity leave) are not provided in main and secondary jobs.

Source: Russian Longitudinal Monitoring Survey - various waves. 
Table 2: Summary of the important determinants of informality by different measures : Russia

\begin{tabular}{|c|c|c|c|c|c|}
\hline & $\begin{array}{c}(1) \\
\text { Informal } \\
\text { employees, } \\
\text { main job }\end{array}$ & $\begin{array}{c}(2) \\
\text { Informal } \\
\text { employees main } \\
\text { or sec. jobs, and } \\
\text { informal self- } \\
\text { employed }\end{array}$ & $\begin{array}{c}\text { (3) } \\
\text { Informal } \\
\text { employees and } \\
\text { working not in } \\
\text { enter. /org, } \\
\text { main and sec. } \\
\text { jobs }\end{array}$ & $\begin{array}{c}\text { (4) } \\
\text { Absence of } \\
\text { three mandatory } \\
\text { benefits, main } \\
\text { and sec. jobs }\end{array}$ & $\begin{array}{c}\text { (5) } \\
\text { Firm size }<5 \\
\text { employees }\end{array}$ \\
\hline Age & $<0$ & $<0$ & $<0$ & $<0$ & $>0$ \\
\hline Male & $>0$ & $>0$ & $>0$ & $>0$ & $<0$ \\
\hline Married & $<0$ & $<0$ & $<0$ & $<0$ & n.s. \\
\hline Sec. edu. level & $<0$ & n.s. & $<0$ & n.s. & $<0$ \\
\hline High edu. level & $<0$ & $<0$ & $<0$ & $<0$ & $<0$ \\
\hline North-West & $<0$ & n.s. & $>0$ & $<0$ & n.s. \\
\hline Central-Volga & $<0$ & $<0$ & $>0$ & $<0$ & $>0$ \\
\hline South & $<0$ & n.s. & $>0$ & $<0$ & $>0$ \\
\hline East & $>0$ & $>0$ & $>0$ & $<0$ & $>0$ \\
\hline City & $<0$ & $<0$ & n.s. & $<0$ & n.s. \\
\hline Village & $<0$ & $<0$ & $<0$ & $<0$ & $>0$ \\
\hline Observations & 50996 & 56100 & 56100 & 42221 & 36169 \\
\hline
\end{tabular}

Notes: Signs of the marginal effects from Probit regression are reported. Specification with year, sector and occupation dummies, without immigrant dummies. Signs shown represent marginal effects that are significant at least at the 10 percent level; n.s.= not significant.

The complete regressions results can be found in tables A2-A6 in the appendix of Lehmann and Zaiceva (2013).

Source: RLMS - pooled data. 
Table 3: Determinants of informal employment by informality status, main job and selfemployment, Russia 2004-2011. Multinomial logit, Marginal effects

\begin{tabular}{|c|c|c|c|c|c|}
\hline & $\begin{array}{c}\text { (1) } \\
\text { Involuntary } \\
\text { informal } \\
\text { employee } \\
\end{array}$ & $\begin{array}{c}\text { (2) } \\
\text { Voluntary } \\
\text { informal } \\
\text { employee } \\
\end{array}$ & $\begin{array}{c}(3) \\
\text { Informal } \\
\text { self- } \\
\text { employed } \\
\end{array}$ & $\begin{array}{c}\text { (4) } \\
\text { Formal self- } \\
\text { employed }\end{array}$ & $\begin{array}{c}\text { (5) } \\
\text { Formal } \\
\text { employee }\end{array}$ \\
\hline Age & $\begin{array}{c}-0.0002^{* * *} \\
(.00004)\end{array}$ & $\begin{array}{l}-0.0001^{* * *} \\
(0.00002)\end{array}$ & $\begin{array}{l}0.0001^{* * *} \\
(0.00001)\end{array}$ & $\begin{array}{c}0.00001 \\
(0.00001)\end{array}$ & $\begin{array}{l}0.0003^{* * * *} \\
(0.00005)\end{array}$ \\
\hline Male & $\begin{array}{c}0.0031^{* * *} \\
(0.0008)\end{array}$ & $\begin{array}{c}0.0019 * * * \\
(0.0006)\end{array}$ & $\begin{array}{c}0.0027^{* * *} \\
(0.0004)\end{array}$ & $\begin{array}{c}0.0012 * * * \\
(0.0002)\end{array}$ & $\begin{array}{c}-0.0088^{* * *} \\
(0.0012)\end{array}$ \\
\hline Married & $\begin{array}{c}-0.0042^{* * *} \\
(0.0009)\end{array}$ & $\begin{array}{c}-0.0021^{* * *} \\
(0.0006)\end{array}$ & $\begin{array}{c}0.0015^{* * *} \\
(0.0003)\end{array}$ & $\begin{array}{c}0.0007 * * * \\
(0.0002)\end{array}$ & $\begin{array}{c}0.0041^{* * *} \\
(0.0011)\end{array}$ \\
\hline Sec. edu. level & $\begin{array}{c}-0.0018^{* *} \\
(0.0009)\end{array}$ & $\begin{array}{l}-0.0012^{*} \\
(0.0006)\end{array}$ & $\begin{array}{c}0.0011^{* * *} \\
(0.0004)\end{array}$ & $\begin{array}{c}0.0007 * * \\
(0.0003)\end{array}$ & $\begin{array}{c}0.0011 \\
(0.0012)\end{array}$ \\
\hline High edu. level & $\begin{array}{c}-0.0061^{* * *} \\
(0.0013)\end{array}$ & $\begin{array}{c}-0.0026 * * * \\
(0.0008)\end{array}$ & $\begin{array}{l}0.0010 * \\
(0.0006)\end{array}$ & $\begin{array}{l}0.0012 * * \\
(0.0005)\end{array}$ & $\begin{array}{c}0.0064^{* * * *} \\
(0.0017)\end{array}$ \\
\hline North-West & $\begin{array}{c}-0.0035^{* *} \\
(0.0014)\end{array}$ & $\begin{array}{l}-0.0020^{* *} \\
(0.0008)\end{array}$ & $\begin{array}{l}0.0021^{* *} \\
(0.0009)\end{array}$ & $\begin{array}{l}-0.00004 \\
(0.0003)\end{array}$ & $\begin{array}{l}0.0035^{*} \\
(0.0020)\end{array}$ \\
\hline Central-Volga & $\begin{array}{c}-0.0008 \\
(0.0010)\end{array}$ & $\begin{array}{c}-0.0045^{* * *} \\
(0.0006)\end{array}$ & $\begin{array}{c}0.0024^{* * *} \\
(0.0005)\end{array}$ & $\begin{array}{l}0.0004 * \\
(0.0002)\end{array}$ & $\begin{array}{l}0.0025^{*} \\
(0.0014)\end{array}$ \\
\hline South & $\begin{array}{l}-0.002{ }^{*} \\
(0.0012)\end{array}$ & $\begin{array}{c}-0.0038^{* * * *} \\
(0.0006)\end{array}$ & $\begin{array}{c}0.0044^{* * *} \\
(0.0009)\end{array}$ & $\begin{array}{l}0.00005 \\
(0.0003)\end{array}$ & $\begin{array}{c}0.0014 \\
(0.0017)\end{array}$ \\
\hline East & $\begin{array}{c}0.0037 * * * \\
(0.0012)\end{array}$ & $\begin{array}{c}-0.0017 * * * \\
(0.0006)\end{array}$ & $\begin{array}{c}0.0022 * * * \\
(0.0006)\end{array}$ & $\begin{array}{l}0.00003 \\
(0.0002)\end{array}$ & $\begin{array}{c}-0.0042^{* * *} \\
(0.0016)\end{array}$ \\
\hline City & $\begin{array}{c}-0.0032^{* * * *} \\
(0.0008)\end{array}$ & $\begin{array}{c}-0.0030 * * * \\
(0.0005)\end{array}$ & $\begin{array}{c}0.0025^{* * *} \\
(0.0004)\end{array}$ & $\begin{array}{l}-0.00004 \\
(0.0002)\end{array}$ & $\begin{array}{c}0.0037 * * * \\
(0.0011)\end{array}$ \\
\hline Village & $\begin{array}{c}-0.0044^{* * * *} \\
(0.0008)\end{array}$ & $\begin{array}{c}-0.0049 * * * \\
(0.0006)\end{array}$ & $\begin{array}{c}-0.0001 \\
(0.0004)\end{array}$ & $\begin{array}{c}-0.0001 \\
(0.0002)\end{array}$ & $\begin{array}{c}0.0096 * * * \\
(0.0011)\end{array}$ \\
\hline Immigrant & $0.0059 * * *$ & $0.0032 * *$ & $0.0089 * * *$ & $0.0013^{* * *}$ & $-0.0193 * * *$ \\
\hline Caucasus, CA & $(0.0021)$ & $(0.0015)$ & (0.0013) & $(0.0005)$ & $(0.0030)$ \\
\hline Immigrant not & $0.0134 * * *$ & $0.0029 *$ & 0.0013 & 0.0003 & $-0.0179 * * *$ \\
\hline CCA, not Russia & (0.0030) & $(0.0017)$ & (0.0009) & (0 .0004) & (0 .0037) \\
\hline Other immigrants & $\begin{array}{c}0.0006 \\
(0.0008)\end{array}$ & $\begin{array}{c}0.0017 * * * \\
(0.0006)\end{array}$ & $\begin{array}{c}-0.0001 \\
(0.0003)\end{array}$ & $\begin{array}{c}-0.0002 \\
(0.0002)\end{array}$ & $\begin{array}{l}-0.0021^{*} \\
(0.0011)\end{array}$ \\
\hline Observations & & 55232 & & & \\
\hline
\end{tabular}

Notes: Robust standard errors in parentheses. ${ }^{* * *} \mathrm{p}<0.01,{ }^{* *} \mathrm{p}<0.05,{ }^{*} \mathrm{p}<0.1$ Reference categories: female, not married, primary education level, Moscow/St. Petersburg, large regional center, non-immigrants; time, industry and occupational dummies were included but are not shown.

Source: RLMS. 
Table 4: Hourly wage gap: Informal employees and those not working in enterprise/organization: Russia 2003-2011

\begin{tabular}{|c|c|c|c|c|c|c|}
\hline & (1) & $\begin{array}{l}(2) \\
\text { OLS }\end{array}$ & (3) & (4) & $\begin{array}{l}\text { (5) } \\
\text { FE }\end{array}$ & (6) \\
\hline Informal employee & $\begin{array}{c}-0.088^{* * *} \\
(0.014)\end{array}$ & $\begin{array}{c}-0.111 * * * \\
(0.014)\end{array}$ & $\begin{array}{c}-0.060^{* * *} \\
(0.014)\end{array}$ & $\begin{array}{c}0.008 \\
(0.018)\end{array}$ & $\begin{array}{c}-0.018 \\
(0.019)\end{array}$ & $\begin{array}{c}-0.011 \\
(0.019)\end{array}$ \\
\hline No enterprise/org. & $\begin{array}{c}0.037 * * * \\
(0.012)\end{array}$ & $\begin{array}{c}0.005 \\
(0.013)\end{array}$ & $\begin{array}{c}0.017 \\
(0.013)\end{array}$ & $\begin{array}{c}0.063 * * * \\
(0.018)\end{array}$ & $\begin{array}{c}0.036^{* *} \\
(0.018)\end{array}$ & $\begin{array}{c}0.040 * * \\
(0.018)\end{array}$ \\
\hline Age & $\begin{array}{c}0.037 * * * \\
(0.002)\end{array}$ & $\begin{array}{c}0.037 * * * \\
(0.002)\end{array}$ & $\begin{array}{c}0.033^{* * *} \\
(0.002)\end{array}$ & $\begin{array}{c}0.073 * * * \\
(0.016)\end{array}$ & $\begin{array}{c}0.070 * * * \\
(0.016)\end{array}$ & $\begin{array}{c}0.066^{* * *} \\
(0.016)\end{array}$ \\
\hline Age squared & $\begin{array}{c}-0.001 * * * \\
(0.000)\end{array}$ & $\begin{array}{c}-0.000^{* * *} \\
(0.000)\end{array}$ & $\begin{array}{c}-0.000^{* * *} \\
(0.000)\end{array}$ & $\begin{array}{c}-0.001^{* * *} \\
(0.000)\end{array}$ & $\begin{array}{c}-0.001^{* * *} \\
(0.000)\end{array}$ & $\begin{array}{c}-0.001^{* * *} \\
(0.000)\end{array}$ \\
\hline Male & $\begin{array}{c}0.300 * * * \\
(0.006)\end{array}$ & $\begin{array}{c}0.233^{* * *} \\
(0.007)\end{array}$ & $\begin{array}{c}0.213^{* * *} \\
(0.008)\end{array}$ & & & \\
\hline Married & $\begin{array}{c}0.065^{* * *} \\
(0.007)\end{array}$ & $\begin{array}{c}0.064^{* * *} \\
(0.007)\end{array}$ & $\begin{array}{c}0.057 * * * \\
(0.007)\end{array}$ & $\begin{array}{c}0.032 * * \\
(0.015)\end{array}$ & $\begin{array}{c}0.037 * * \\
(0.015)\end{array}$ & $\begin{array}{c}0.038^{* *} \\
(0.015)\end{array}$ \\
\hline Sec. edu. & $\begin{array}{c}0.166^{* * *} \\
(0.010)\end{array}$ & $\begin{array}{c}0.144^{* * *} \\
(0.009)\end{array}$ & $\begin{array}{c}0.096 * * * \\
(0.009)\end{array}$ & $\begin{array}{c}0.018 \\
(0.025)\end{array}$ & $\begin{array}{c}0.024 \\
(0.025)\end{array}$ & $\begin{array}{c}0.028 \\
(0.025)\end{array}$ \\
\hline Higher edu. & $\begin{array}{c}0.504^{* * *} \\
(0.011)\end{array}$ & $\begin{array}{c}0.494 * * * \\
(0.011)\end{array}$ & $\begin{array}{c}0.304^{* * *} \\
(0.012)\end{array}$ & $\begin{array}{c}0.006 \\
(0.039)\end{array}$ & $\begin{array}{c}0.001 \\
(0.038)\end{array}$ & $\begin{array}{c}-0.007 \\
(0.038)\end{array}$ \\
\hline city & $\begin{array}{c}-0.145^{* * *} \\
(0.008)\end{array}$ & $\begin{array}{c}-0.153^{* * *} \\
(0.008)\end{array}$ & $\begin{array}{c}-0.155^{* * *} \\
(0.008)\end{array}$ & $\begin{array}{c}-0.021 \\
(0.181)\end{array}$ & $\begin{array}{c}-0.072 \\
(0.143)\end{array}$ & $\begin{array}{c}-0.084 \\
(0.147)\end{array}$ \\
\hline village & $\begin{array}{c}-0.439 * * * \\
(0.009)\end{array}$ & $\begin{array}{c}-0.342^{* * *} \\
(0.009)\end{array}$ & $\begin{array}{c}-0.330^{* * *} \\
(0.009)\end{array}$ & & & \\
\hline Region dummies & Yes & Yes & Yes & Yes & Yes & Yes \\
\hline Year dummies & Yes & Yes & Yes & Yes & Yes & Yes \\
\hline Sector dummies & No & Yes & Yes & No & Yes & Yes \\
\hline Occupation dummies & No & No & Yes & No & No & Yes \\
\hline Constant & $\begin{array}{c}2.941 * * * \\
(0.039)\end{array}$ & $\begin{array}{c}2.936 * * * \\
(0.041)\end{array}$ & $\begin{array}{c}2.793 * * * \\
(0.041)\end{array}$ & $\begin{array}{c}1.773^{* * *} \\
(0.533)\end{array}$ & $\begin{array}{c}1.847 * * * \\
(0.545)\end{array}$ & $\begin{array}{c}1.821^{* * *} \\
(0.536)\end{array}$ \\
\hline Observations & 47303 & 43153 & 43094 & 47303 & 43153 & 43094 \\
\hline R-squared & 0.45 & 0.45 & 0.47 & 0.42 & 0.38 & 0.38 \\
\hline
\end{tabular}

Notes: Robust standard errors in parentheses. * significant at 10\%; ** significant at 5\%; *** significant at $1 \%$. Wages are based on wage in the last 30 days, main job. "No enterprise/org." stands for " not working in enterprise or organization."

Source: RLMS (2003 - 2011). 
Table 5. Average measures of risk attitudes for informal, formal and self-employed work $\underline{\text { Ukraine } 2007}$

\begin{tabular}{|c|c|c|c|c|c|c|}
\hline \multirow[t]{2}{*}{ 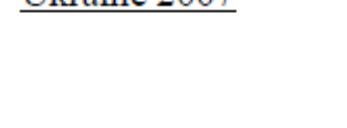 } & \multicolumn{2}{|l|}{ Informal employees } & \multicolumn{2}{|c|}{ Formal employees } & \multicolumn{2}{|l|}{ Self-employed 1/ } \\
\hline & Average of Risk & $\mathrm{N}$ & Average of Risk & $\mathrm{N}$ & Average of Risk & $\mathrm{N}$ \\
\hline All & 4.634 & 298 & 3.692 & 2725 & 4.786 & 379 \\
\hline \multicolumn{7}{|l|}{ Gender } \\
\hline Men & 5.325 & 166 & 4.334 & 1332 & 5.192 & 214 \\
\hline Women & 3.765 & 132 & 3.078 & 1393 & 4.261 & 165 \\
\hline \multicolumn{7}{|l|}{ Age Group } \\
\hline $15-25$ & 5.302 & 96 & 4.575 & 388 & 5.237 & 38 \\
\hline $26-35$ & 5.256 & 78 & 4.139 & 583 & 5.250 & 76 \\
\hline $36-45$ & 3.887 & 62 & 3.557 & 687 & 4.817 & 120 \\
\hline $46-55$ & 3.467 & 45 & 3.097 & 725 & 4.330 & 106 \\
\hline $56-65$ & 3.692 & 13 & 3.544 & 283 & 4.935 & 31 \\
\hline $65+$ & 4.250 & 4 & 3.068 & 59 & 3.250 & 8 \\
\hline \multicolumn{7}{|l|}{ Education 3/ } \\
\hline High School & 4.159 & 69 & 3.710 & 455 & 4.613 & 75 \\
\hline University & 5.125 & 24 & 3.995 & 646 & 5.600 & 65 \\
\hline \multicolumn{7}{|l|}{ Married } \\
\hline Yes & 3.741 & 135 & 3.537 & 1811 & 4.792 & 255 \\
\hline No & 5.374 & 163 & 4.002 & 921 & 4.774 & 124 \\
\hline \multicolumn{7}{|l|}{ Kids 4/ } \\
\hline Yes & 4.237 & 97 & 3.586 & 1064 & 4.576 & 139 \\
\hline No & 5.364 & 33 & 3.468 & 408 & 4.551 & 78 \\
\hline \multicolumn{7}{|l|}{ Region } \\
\hline Kiev & 7.000 & 10 & 3.409 & 154 & 5.214 & 14 \\
\hline Center & 4.015 & 65 & 3.699 & 667 & 4.688 & 96 \\
\hline West & 4.745 & 47 & 3.911 & 471 & 5.684 & 76 \\
\hline East & 4.795 & 78 & 3.590 & 748 & 4.771 & 83 \\
\hline South & 4.622 & 98 & 3.711 & 685 & 4.209 & 110 \\
\hline \multicolumn{7}{|l|}{ Registration details 5/ } \\
\hline Registered Self-employed & $\ldots$ & $\ldots$ & $\ldots$ & $\ldots$ & 4.926 & 162 \\
\hline $\begin{array}{l}\text { Not registered Self- } \\
\text { employed }\end{array}$ & $\cdots$ & $\ldots$ & $\ldots$ & $\cdots$ & 4.702 & 218 \\
\hline Involuntary informal & 4.500 & 200 & $\ldots$ & $\ldots$ & $\ldots$ & $\ldots$ \\
\hline Voluntary informal & 4.988 & 84 & $\ldots$ & $\ldots$ & $\ldots$ & $\ldots$ \\
\hline \multirow{2}{*}{\multicolumn{7}{|c|}{$\begin{array}{l}\text { Source: Dohmen, Khamis and Lehmann (2014). Calculations based on Ukrainian Longitudinal Monitoring Survey } \\
\text { (ULMS) } 2007 . \\
\text { Notes: }\end{array}$}} \\
\hline & & & & & & \\
\hline \multicolumn{7}{|c|}{ 1/ Self-employed: this category includes self-employed and entrepreneurs/employers. } \\
\hline \multicolumn{7}{|c|}{$2 / \mathrm{N}$ : number of observations. } \\
\hline \multicolumn{7}{|c|}{ 3/ Completed level. } \\
\hline \multicolumn{7}{|l|}{ 4/ Kids: kids in household } \\
\hline 5/ Involuntary informal: es & loyer does not want $t$ & regist & Voluntary infor & $\mathrm{em}$ & or employ & \\
\hline
\end{tabular}


Table 6. Risk measures and informal employment: Russia (2009) and Ukraine (2007) Marginal effects of Probit regressions. Dependent variable: Probability of being informally employed

\section{Russia}

Risk index

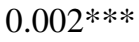

$(0.001)$

Risk indicator

$$
(0.005)
$$

Financial Risk index.

Financial Risk indicator.

$$
\begin{gathered}
0.002 * * * \\
(0.001)
\end{gathered}
$$

Observations

$$
5234
$$

Ukraine

Risk index $0.004 * * *$

Risk indicator

[0.002]

Career risk index

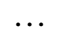

$$
\text { ... }
$$

...

[0.011]

Career risk indicator

...

$$
\cdots
$$

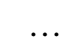

$\cdots$

…

...

Observations

2429

2429

Notes: Robust standard errors in parentheses. */**/*** significant at 10\%/5\%/1\% respectively. Controls not shown include demographics, income, migration status as well as sector, occupation and region dummies.

Sources: Russia - RLMS (2009); Ukraine - ULMS (2007). 
Table 7: Risk index and selection into labour market states, 2009: Multinomial logit estimates relative odds ratios

\begin{tabular}{|c|c|c|c|c|}
\hline & $\begin{array}{c}\text { involuntary informal } \\
\text { employee }\end{array}$ & $\begin{array}{c}\text { voluntary informal } \\
\text { employee }\end{array}$ & $\begin{array}{l}\text { informal self- } \\
\text { employed }\end{array}$ & formal self-employed \\
\hline General Risk index & $\begin{array}{l}1.048 \\
(1.47)\end{array}$ & $\begin{array}{c}1.090^{* *} \\
(2.38)\end{array}$ & $\begin{array}{c}1.115^{* * *} \\
(3.39)\end{array}$ & $\begin{array}{l}1.225^{* * *} \\
(3.66)\end{array}$ \\
\hline Age & $\begin{array}{c}0.998 \\
(-0.18)\end{array}$ & $\begin{array}{c}0.972^{* *} \\
(-2.16)\end{array}$ & $\begin{array}{c}1.036 * * * \\
(3.30)\end{array}$ & $\begin{array}{l}1.041^{* *} \\
(2.38)\end{array}$ \\
\hline Male & $\begin{array}{c}1.669 * * * \\
(2.60)\end{array}$ & $\begin{array}{l}1.412 \\
(1.25)\end{array}$ & $\begin{array}{c}2.464 * * * \\
(4.38)\end{array}$ & $\begin{array}{l}1.879 * \\
(1.71)\end{array}$ \\
\hline Married & $\begin{array}{l}0.670 * \\
(-1.64)\end{array}$ & $\begin{array}{c}0.763 \\
(-0.86)\end{array}$ & $\begin{array}{c}0.880 \\
(-0.46)\end{array}$ & $\begin{array}{l}1.954 \\
(0.99)\end{array}$ \\
\hline Child & $\begin{array}{c}0.916 \\
(-0.58)\end{array}$ & $\begin{array}{l}1.001 \\
(0.01)\end{array}$ & $\begin{array}{l}1.394 * * * \\
(2.91)\end{array}$ & $\begin{array}{l}1.141 \\
(0.70)\end{array}$ \\
\hline Secondary education & $\begin{array}{c}0.766 \\
(-1.06)\end{array}$ & $\begin{array}{c}0.577 * * \\
(-2.01)\end{array}$ & $\begin{array}{l}1.545 \\
(1.30)\end{array}$ & $\begin{array}{l}2.114 \\
(0.95)\end{array}$ \\
\hline Higher education & $\begin{array}{c}0.306 * * * \\
(-2.98)\end{array}$ & $\begin{array}{c}0.248 * * * \\
(-3.22)\end{array}$ & $\begin{array}{l}1.138 \\
(0.34)\end{array}$ & $\begin{array}{c}5.594 * * \\
(2.07)\end{array}$ \\
\hline Log of hh income & $\begin{array}{c}0.879 \\
(-0.75)\end{array}$ & $\begin{array}{c}0.824 \\
(-1.00)\end{array}$ & $\begin{array}{l}1.227 \\
(1.32)\end{array}$ & $\begin{array}{l}2.364 * * * \\
(2.88)\end{array}$ \\
\hline Northwest & $\begin{array}{c}0.237 * * \\
(-2.29)\end{array}$ & $\begin{array}{c}0.745 \\
(-0.71)\end{array}$ & $\begin{array}{l}1.242 \\
(0.45)\end{array}$ & $\begin{array}{l}2.346 \\
(1.08)\end{array}$ \\
\hline Central-Volga & $\begin{array}{c}0.552 * * \\
(-2.11)\end{array}$ & $\begin{array}{c}0.424 * * * \\
(-2.62)\end{array}$ & $\begin{array}{l}1.893^{*} \\
(1.90)\end{array}$ & $\begin{array}{c}3.742 * * \\
(2.24)\end{array}$ \\
\hline South & $\begin{array}{l}0.521^{*} \\
(-1.83)\end{array}$ & $\begin{array}{c}0.215^{* * *} \\
(-3.27)\end{array}$ & $\begin{array}{l}1.716 \\
(1.51)\end{array}$ & $\begin{array}{l}1.783 \\
(0.85)\end{array}$ \\
\hline East & $\begin{array}{c}0.856 \\
(-0.52)\end{array}$ & $\begin{array}{c}0.429 * * \\
(-2.28)\end{array}$ & $\begin{array}{l}1.653 \\
(1.45)\end{array}$ & $\begin{array}{c}3.878 * * \\
(2.34)\end{array}$ \\
\hline Sectors & YES & YES & YES & YES \\
\hline $\begin{array}{l}\text { Observations } \\
\text { Pseudo R2 }\end{array}$ & \multicolumn{4}{|c|}{$\begin{array}{l}4165 \\
0.17\end{array}$} \\
\hline
\end{tabular}

Notes: Relative Odds Ratios are reported. z-statistics in parentheses, standard errors are robust. * significant at 10\%; ** significant at $5 \%$; *** significant at $1 \%$. Base category - formal employees. General risk is measured on a scale from 0 to 10 . 
Figure 1: Share of informal employment by industry, Russia: 2005 and 2011

a) Not officially employed (without work contract/agreement) at the main job

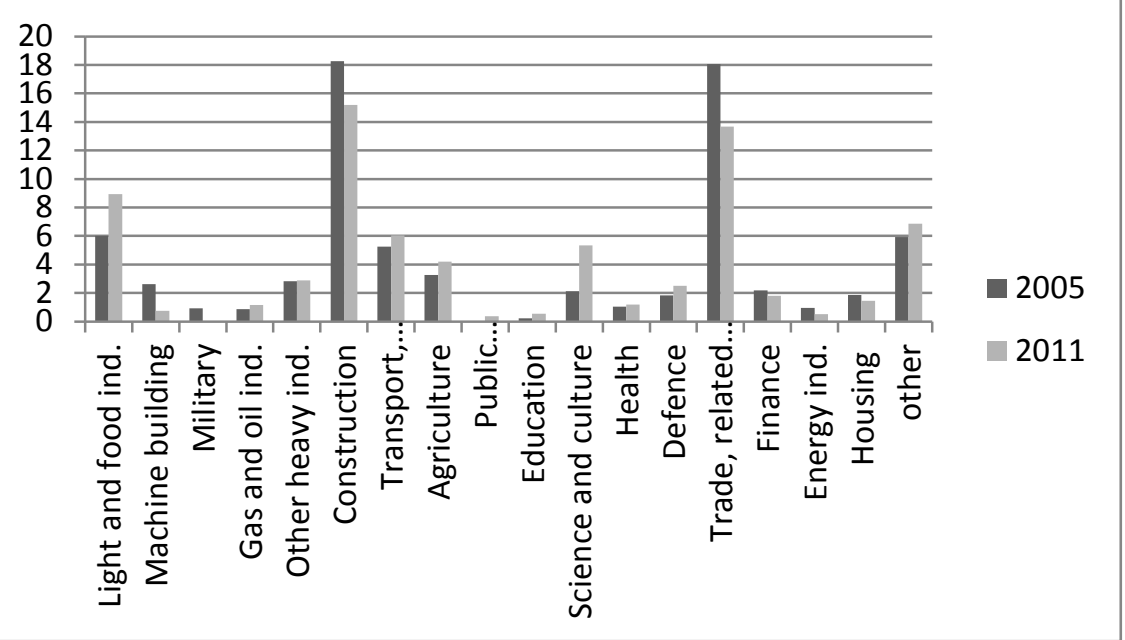

b) Not officially employed and not in enterpr./org. at the main or second job

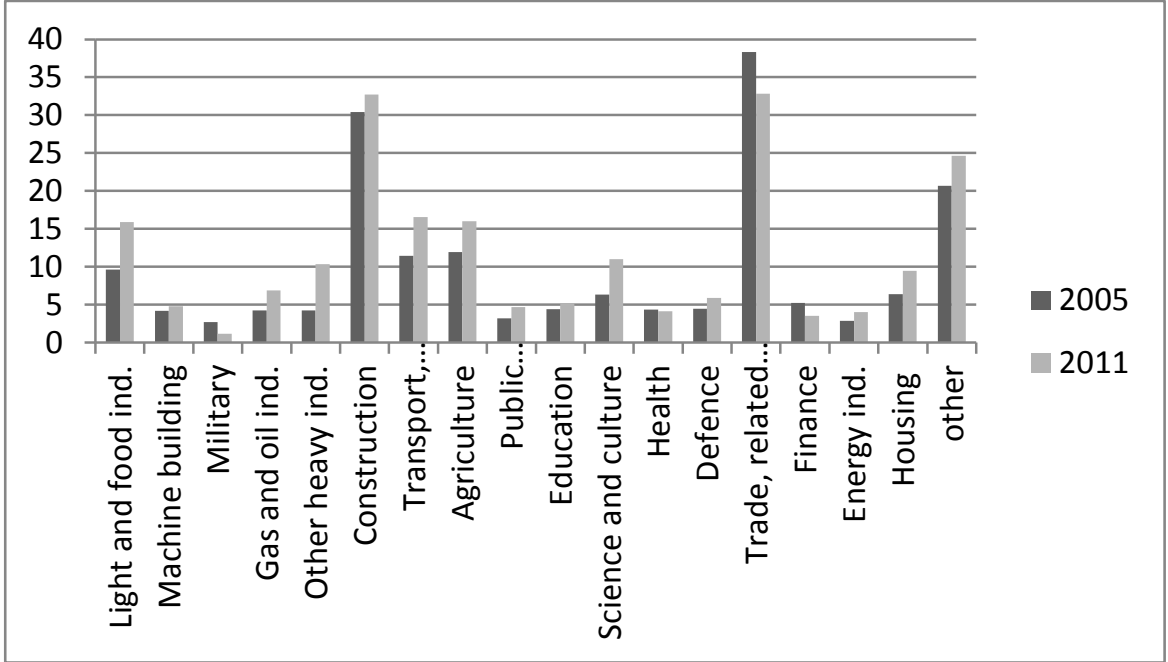

Source: Lehmann and Zaiceva (2013). 
Figure 2: Share of informal employment (firm size) by industry: Russia 2005 and 2011

a) Equal or less than 5 employees

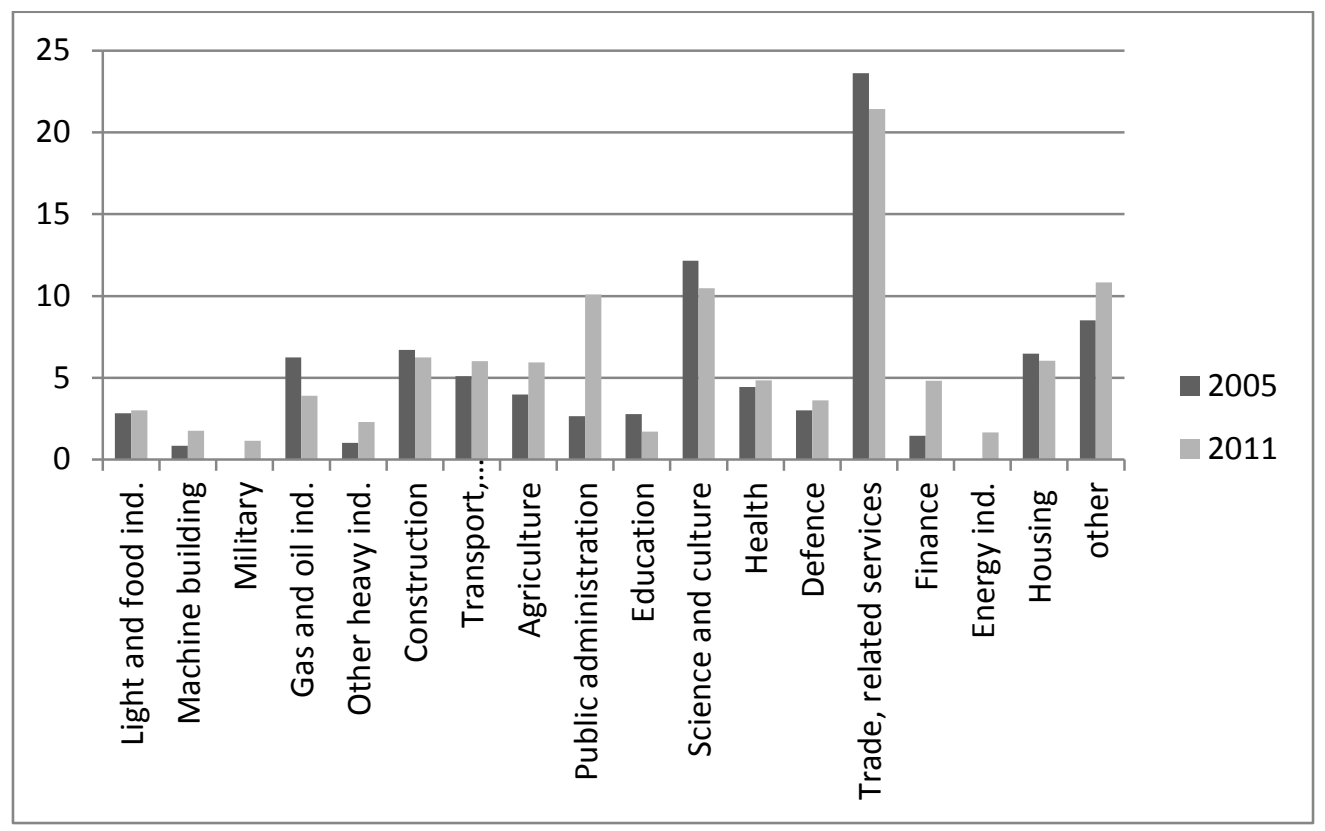

b) Equal or less than 10 employees

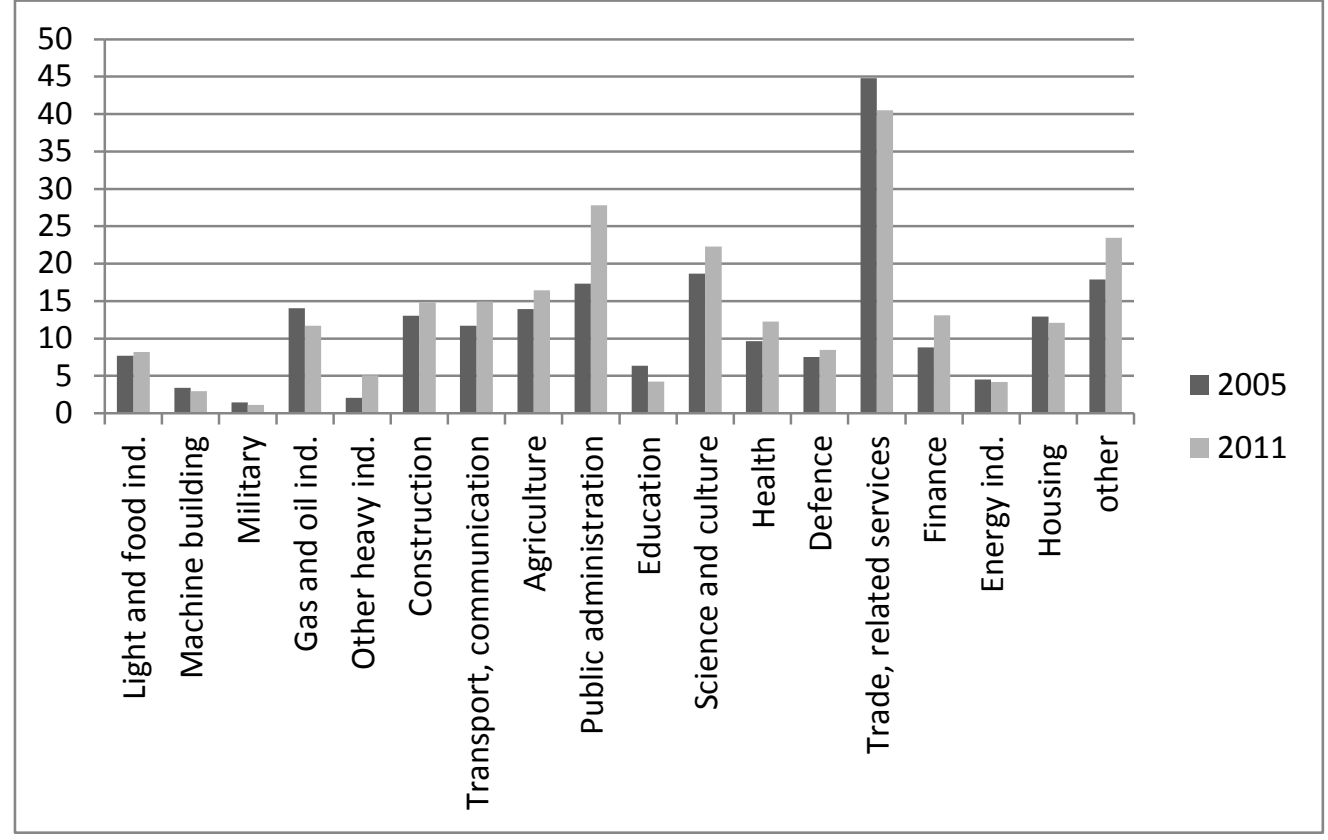

Source: Authors’ calculations. 
Figure 3: Hourly wage gap - Russia: Coefficients from quantile regressions, 2004-2011

a) Informal employees

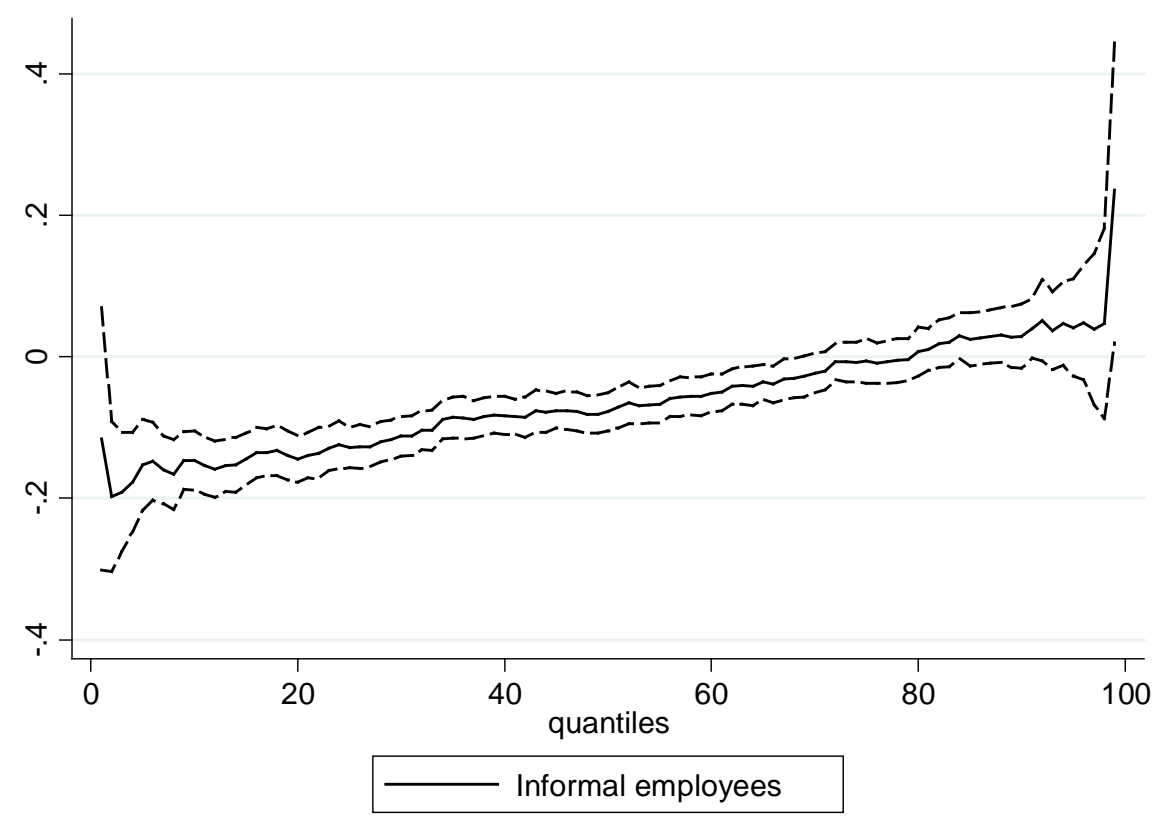

b) Informal employees and not working in enterprise/organization

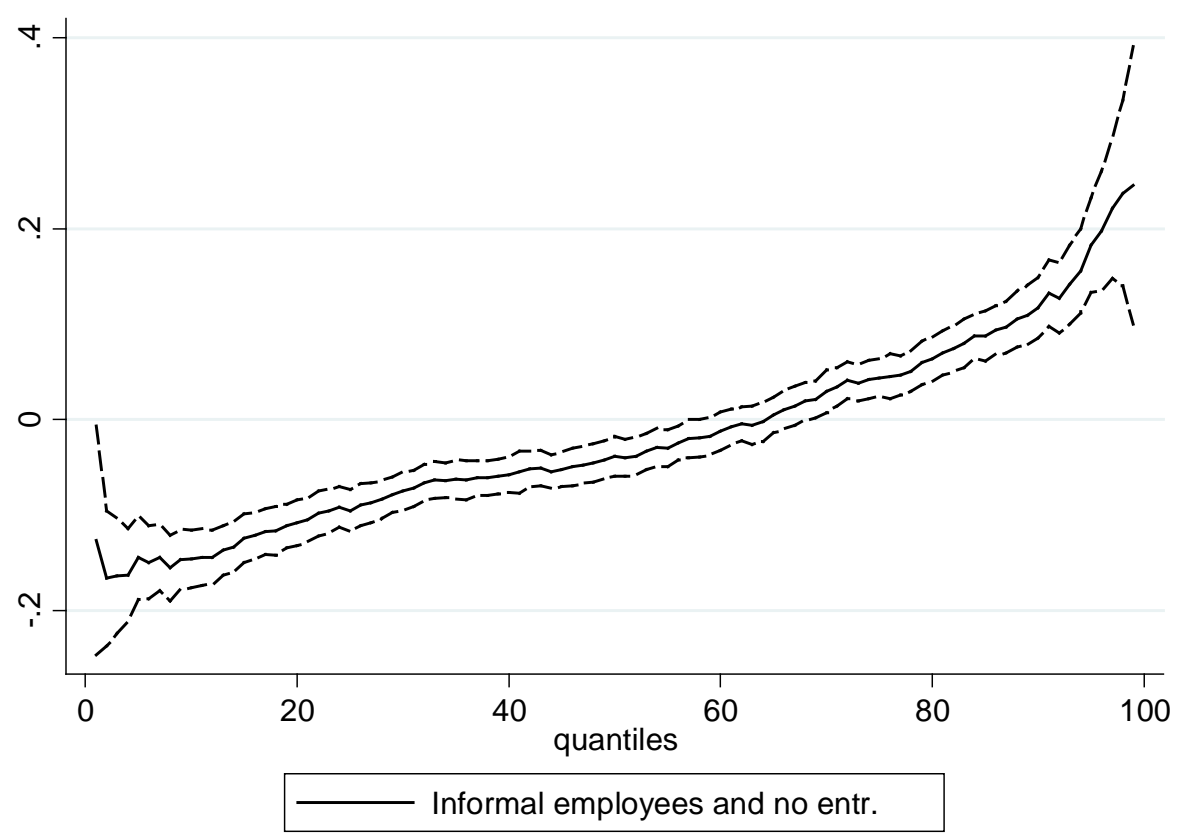

Source: Lehmann and Zaiceva (2013). Data based on pooled data of RLMS 2003-2011. Broken lines are 95\%confidence intervals. 
Figure 4. General Risk attitudes: Ukraine 2007

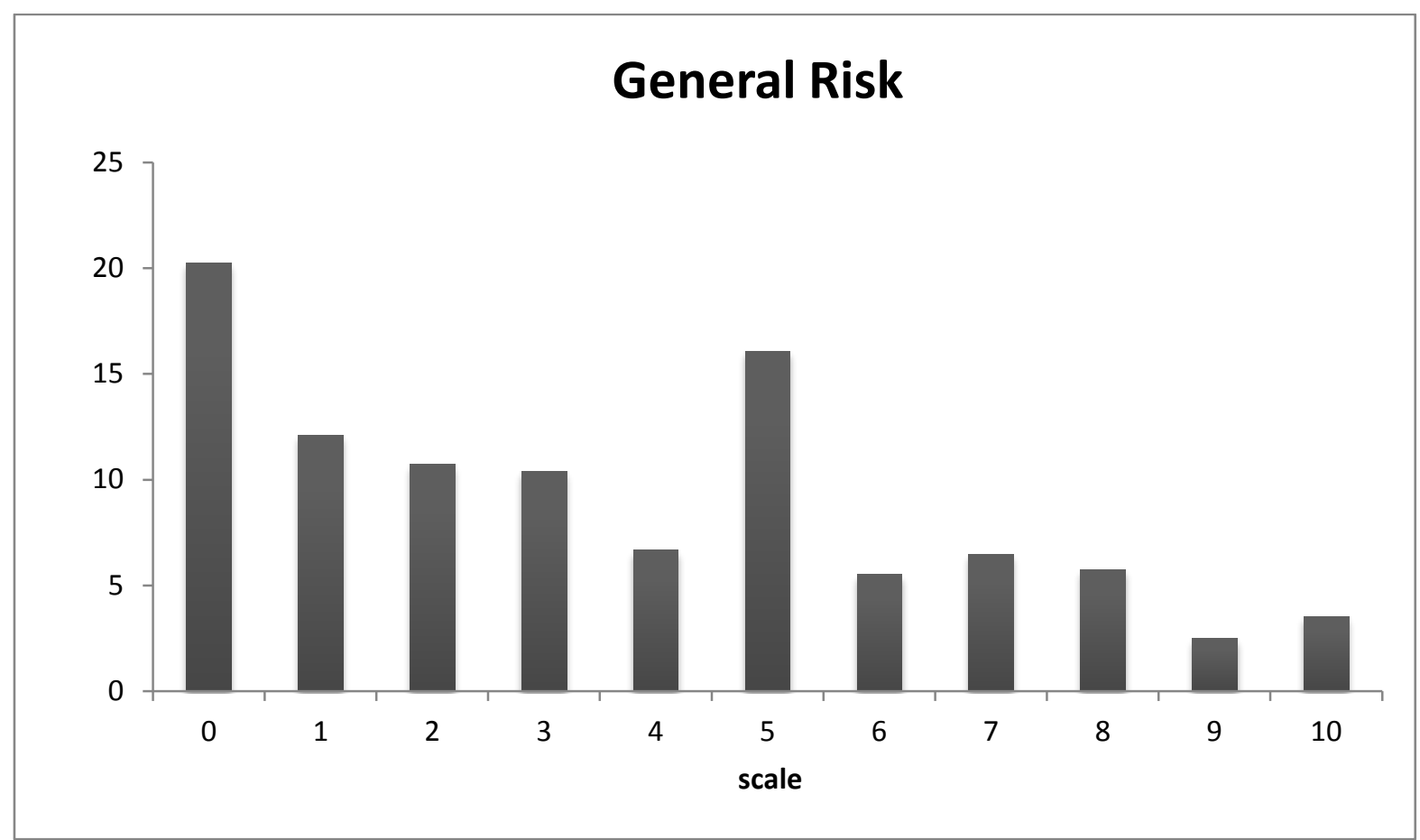

Source: Dohmen, Khamis and Lehmann (2014); figure is based on the ULMS 2007 data.

Figure 5. General Risk attitudes: Russia 2009

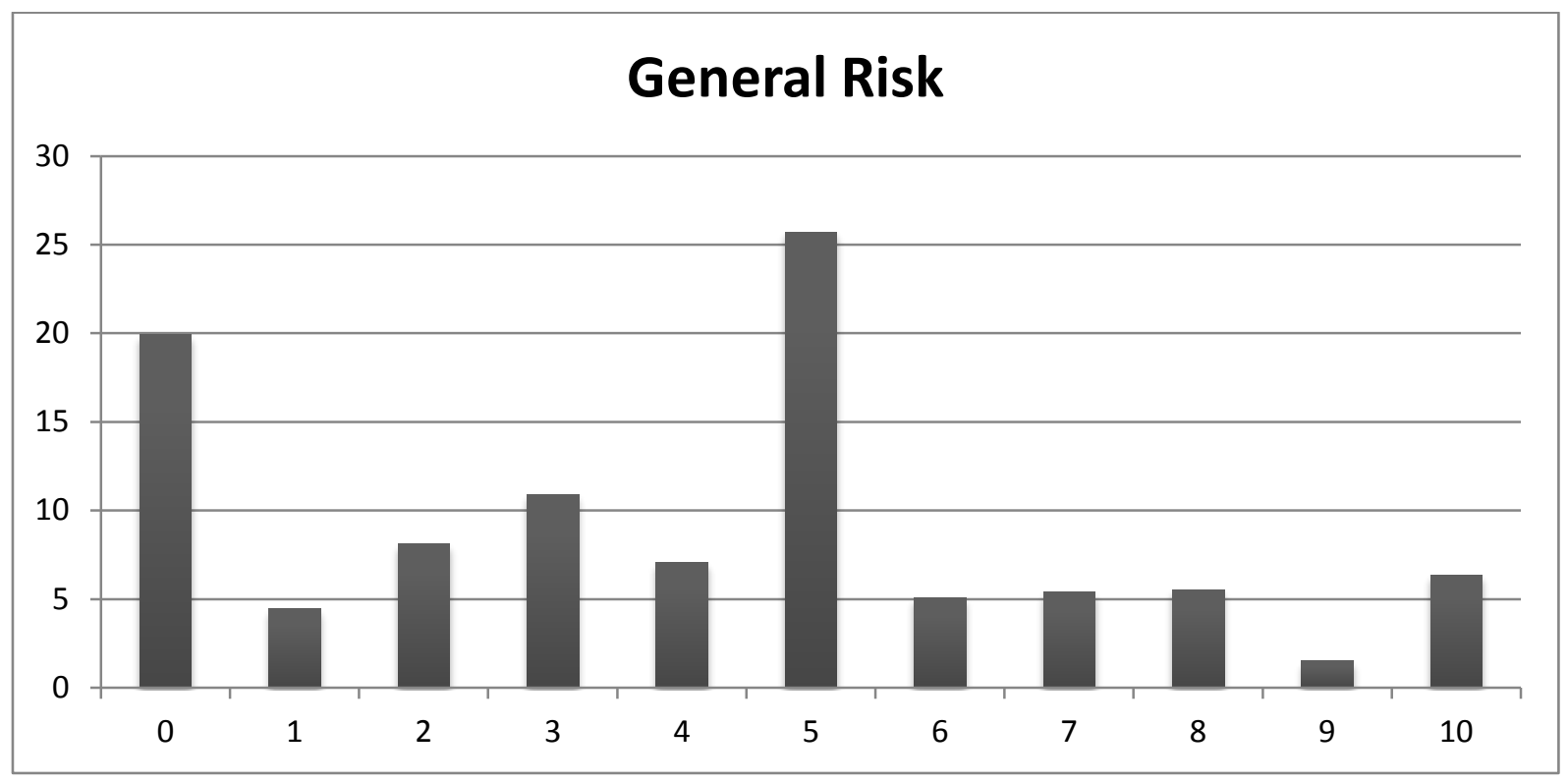

Source: Lehmann and Zaiceva (2013); figure is based on RLMS supplement 2009. 
Figure 6. Risk attitudes and employment category: Ukraine 2007

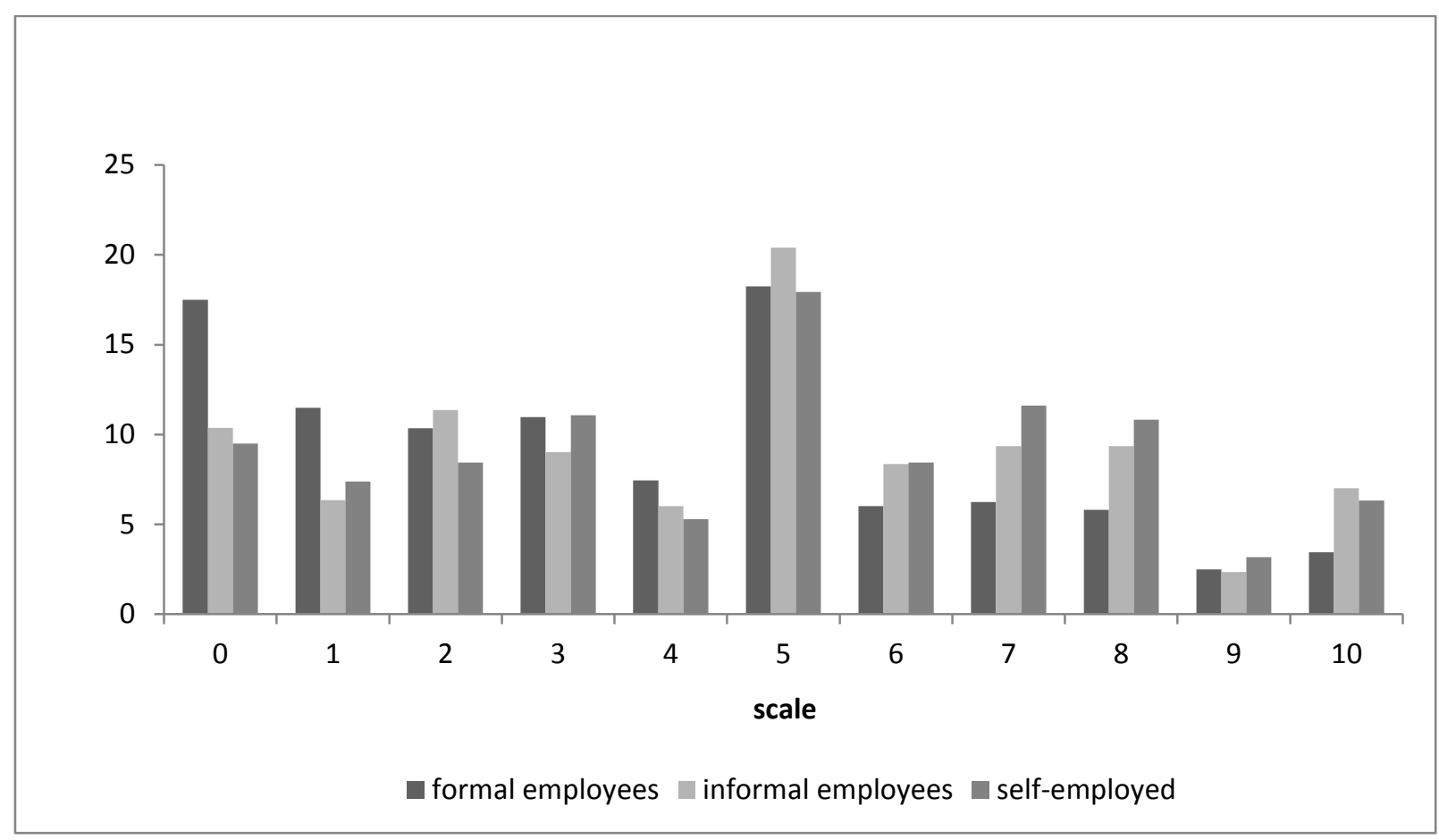

Source: Dohmen, Khamis and Lehmann (2014); figure is based on the ULMS 2007 data.

Figure 7. Risk attitudes and employment category: Russia 2009

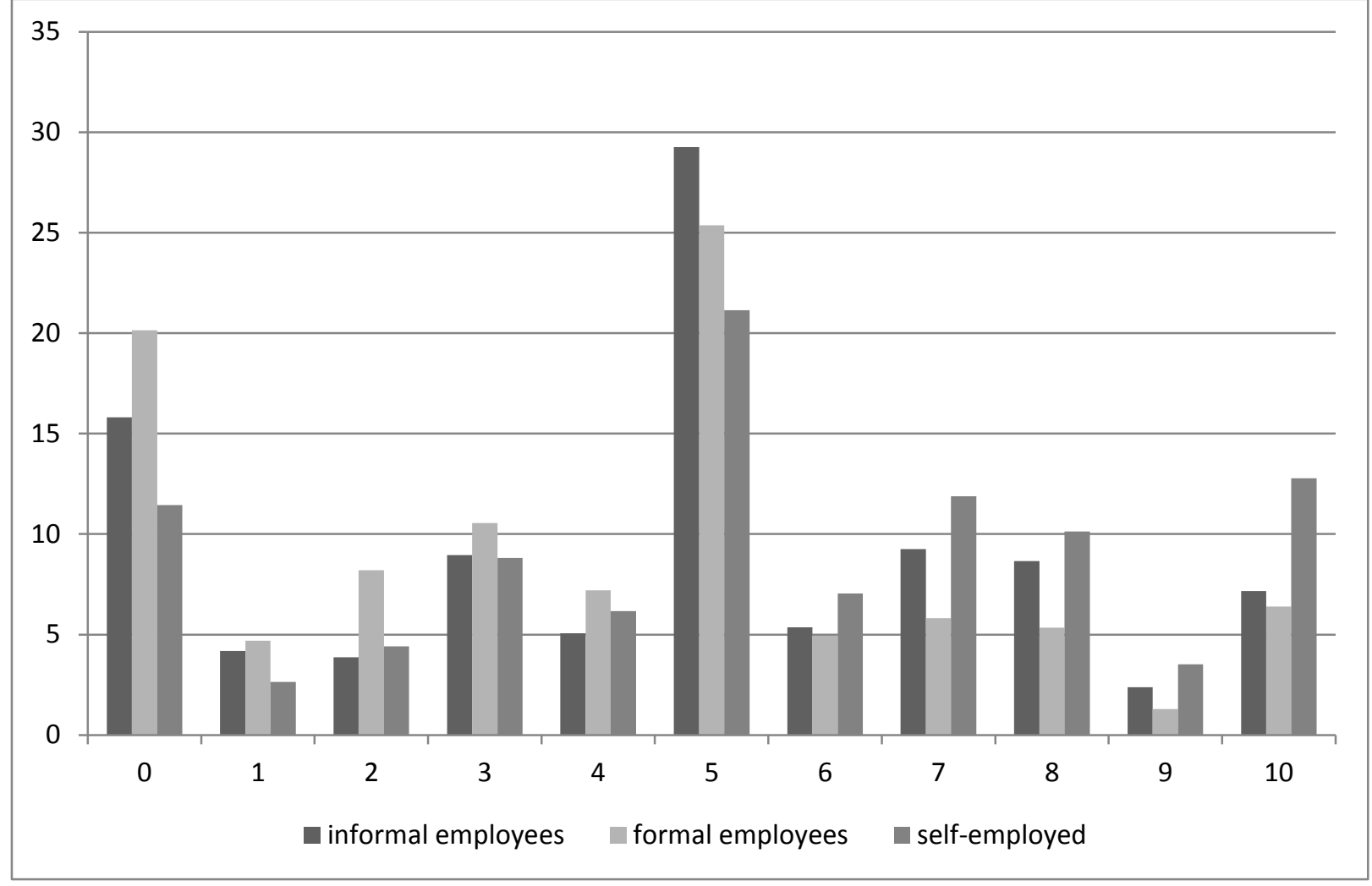

Source: Lehmann and Zaiceva (2013); figure is based on RLMS supplement 2009. 


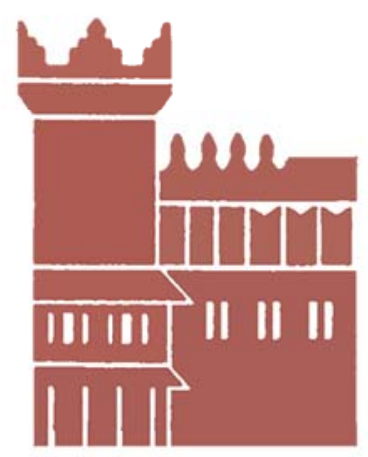

Alma Mater Studiorum - Università di Bologna DEPARTMENT OF ECONOMICS

Strada Maggiore 45

40125 Bologna - Italy

Tel. +39051 2092604

Fax +390512092664

http://www.dse.unibo.it 